\title{
Abanico East Formation: petrology and geochemistry of volcanic rocks behind the Cenozoic arc front in the Andean

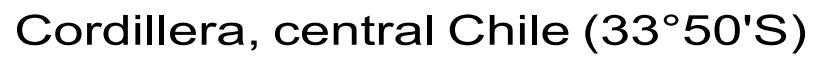

\author{
Marcia Muñoz \\ Francisco Fuentes \\ Mario Vergara \\ Luis Aguirre
}

Jan Olov Nyström

Gilbert Féraud

Alain Demant
Departamento de Geología, Universidad de Chile, Casilla 13518, Correo 21, Santiago, Chile

marmunoz@ing.uchile.cl ffuentes@ing.uchile.cl

mariover@ing.uchile.cl luaguirr@ing.uchile.cl

Swedish Museum of Natural History, SE-10405 Stockholm, Sweden

mi-jan@nrm.se

UMR Géosciences Azur, CNRS-UNSA, Université de NiceSophia Antipolis, 06108 Nice Cedex 02, France feraud@unice.fr

Laboratoire de Pétrologie Magmatique Université Aix-Marseille III, 13397 Marseille Cedex 20, France alain.demant@univ.u-3mrs.fr

\begin{abstract}
The stratigraphy, chemistry and age of rocks assigned to the eastern portion of the Abanico Formation exposed along the EI Volcán river valley, Principal Cordillera east of Santiago (30 $\left.50^{\prime} \mathrm{S} / 70^{\circ} 12^{\prime}-70^{\circ} 5^{\prime} \mathrm{W}\right)$, are reported and discussed. This ca. 3,300 m thick succession is mainly composed of basalts, basaltic andesites and volcaniclastic rocks. ${ }^{40} \mathrm{Ar} /{ }^{39} \mathrm{Ar}$ radiometric dates on plagioclase from the lava flows yield Oligocene-lower Miocene ages with a maximum age of 34.3 $\pm 0.4 \mathrm{Ma}$ for the lower part and a plateau age of 21.4 $\pm 1.0 \mathrm{Ma}$ for the upper part of the succession. The lava flows show calc-alkaline affinities and have chemical characteristics that are typical of arc volcanic rocks erupted in an active continental margin. A temporal chemical evolution in the sequence is indicated by upward increases in concentrations of LILE and LREE elements and $\mathrm{La}_{\mathrm{N}} / \mathrm{Yb}_{\mathrm{N}}$ ratios. This pattern can be attributed to increasing contributions of fluids derived from the subducted lithosphere with time. A chemical comparison of these rocks with Oligocene-lower Miocene volcanic rocks from the Cerro Abanico and Chacabuco areas on the western border of the Principal Cordillera, east of Santiago, and at the northern end of the Central Depression reveals west to east compositional variations. From west to east these variations include: (1) increasing LILE and LREE concentrations, $\mathrm{La}_{\mathrm{N}} / \mathrm{Yb}_{\mathrm{N}}$ ratios and $\mathrm{Sr}$ and $\mathrm{Nd}$ initial isotopic ratios, and (2) decreasing LILE/HFSE and LREE/HFSE ratios. These pattern can be attributed to a west to east decrease in the contribution of slab derived fluids and increase in the influence of crustal contamination processes.
\end{abstract}

Key words: Volcanism, Geochemistry, Oligocene-Lower Miocene, Andes, Chile.

Revista Geológica de Chile, Vol. 33, No. 1, p. 109-140, 16 Figs., 6 tables, January 2006. 


\section{RESUMEN}

La formación Abanico Este: petrología y geoquímica de las rocas volcánicas detrás del arco

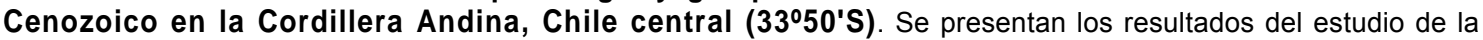
estratigrafía, química y edades de rocas asignadas a la franja oriental de la Formación Abanico expuestas en la ladera sur del Río Volcán, Cordillera Principal al este de Santiago (3050'S, $\left.70^{\circ} 12^{\prime} / 70^{\circ} 5^{\prime} \mathrm{W}\right)$. La serie expuesta, de ca. $3.300 \mathrm{~m}$ de espesor, está compuesta predominantemente por basaltos, andesitas basálticas y rocas volcanoclásticas. Dataciones radiométricas ${ }^{40} \mathrm{Ar} /{ }^{39} \mathrm{Ar}$ en plagioclasa de flujos de lava entregaron edades entre el Oligoceno-Mioceno inferior con una

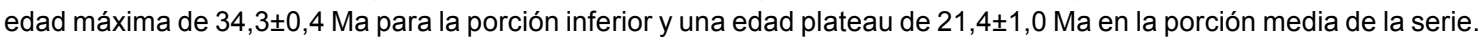
Las lavas poseen una afinidad calcoalcalina y características típicas de rocas volcánicas de arco desarrollado en un margen continental activo. Estas definen un patrón químico de evolución temporal representado por un aumento de concentraciones de elementos LILE, LREE y razones $\mathrm{La}_{\mathrm{N}} / \mathrm{Yb}_{\mathrm{N}}$, el que ha sido atribuido a un aumento de la influencia del componente de subducción con el tiempo. La comparación geoquímica de estas rocas con las rocas volcánicas Oligoceno-Mioceno inferior de las áreas de Cerro Abanico y Chacabuco, ubicadas en el borde occidental de la Cordillera Principal al este de Santiago y límite norte de la Depresión Central, respectivamente, muestra la existencia de variaciones composicionales transversales del volcanismo Oligoceno-Mioceno inferior. Estas variaciones, de oeste a este, corresponden a: (1) incremento en las concentraciones de elementos LILE, LREE y HFSE, razones $L a_{N} / Y_{N}$ y razones iniciales de $\mathrm{Sr}$ y $\mathrm{Nd}$, y (2) disminución de razones LILE/HFSE y LREE/HFSE. Estos patrones pueden ser atribuidos a una disminución de la influencia del componente de subducción y aumento de la intensidad de procesos de contaminación cortical de oeste a este.

Palabras claves: Volcanismo, Geoquímica, Oligoceno-Mioceno inferior, Andes, Chile.

\section{INTRODUCTION}

The Andean Principal Cordillera in central Chile $\left(33^{\circ}-34^{\circ} \mathrm{S}\right)$ is composed mainly of Cenozoic volcanic and continental volcaniclastic rocks forming a northsouth-trending continuous belt. These Cenozoic deposits overlie Mesozoic marine and continental units, which are distributed in a tight belt near the Chilean-Argentinian border. Between 33 and $34^{\circ} \mathrm{S}$, the Cenozoic deposits are known as Abanico Formation (Aguirre, 1960; Klohn, 1960) of Late Eocene-early Miocene age (Vergara et al., 1999; Charrier et al., 2002) and Farellones Formation (Klohn, 1960) of Miocene age (Munizaga and Vicente, 1982; Vergara et al., 1988). The Abanico Formation forms two parallel north-south-oriented bands, separated by the overlying Farellones Formation (Fig. 1). The distribution in two bands of the Abanico Formation has given origin to the informal terminology of Abanico West and Abanico East formations. According to Charrier et al. (2002) an unconformity and a hiatus of ca. 80 Ma separate Abanico East formation from the underlying Mesozoic units.

Both bands of Abanico Formation have been interpreted as deposited simultaneously along the two flanks of a volcano-tectonic intermontane basin (Vergara and Drake, 1979) or as deposited in a north-south oriented extensive and subsident intraarc basin (Godoy et al., 1999; Charrier et al., 2002). This basin, or basin system, was formed upon a ca. 30-35 km thick continental crust during the late Eocene-early Miocene (S.M. Kay and A. Kurtz'; Kay et al., 1999, 2005; Charrier et al., 2002; Kay and Mpodozis, 2002; Nyström et al., 2003; Fuentes, 2004). The deposition of Abanico Formation in it would have generated very low-grade metamorphic assemblages characteristic of extensional settings in all these rocks (Levi et al., 1989; Bevins et al., 2003; Robinson et al. , 2004). The tectonic inversion of the extensional basin began during the early Miocene (Godoy et al., 1999; Charrier et al., 2002).

The volcanism that produced the rocks of the Abanico Formation was related to the subduction of the Nazca (Farallon) oceanic plate under South America. Several studies indicate that Abanico West formation volcanic rocks represent a continental tholeiitic arc (Kay and Mpodozis, 2002; Nyström et

\footnotetext{
11995. Magmatic and tectonic characterization of the El Teniente region. Final report (Unpublished), Division El Teniente-
} Corporación del Cobre: 180 p. Chile. 
al., 2003; Fuentes, 2004). Since the Abanico East formation is located to the east of the previous one, their deposits can be considered as volcanic products from behind the frontal arc. However, compared with the Abanico West formation, petrological and geochemical data of these rocks are almost null or non-existent, the studies carried out in it having been mainly of stratigraphic and structural nature (Baeza, 1999; Elgueta et al. , 2000; Medina, 2001; Bustamante, 2001; Charrier et al., 2002). Consequently, the understanding of the composition and origin of Abanico East formation volcanic rocks is still limited and additional data are needed to constrain petrogenetic and tectonic models for it. The present study represents a stratigraphic and mainly petrological contribution to the knowledge of this formation. A study of a $7 \mathrm{~km}$ long, eastwest oriented cross-section was carried out in rocks assigned to the Abanico East formation in the Andean Principal Cordillera, east of Santiago (Thiele, 1980; Fig. 1). This cross-section covers the outcrops exposed along the El Volcán valley between La Colorada river to the east and the contact with the San Gabriel pluton to the west (3050'S, 70¹2'-705'W; Fig. 1). A second profile located directly to the north, at the Rodeo de Los Bueyes River area, was also performed in order to complete the main section (Fig. 1). The aim of this
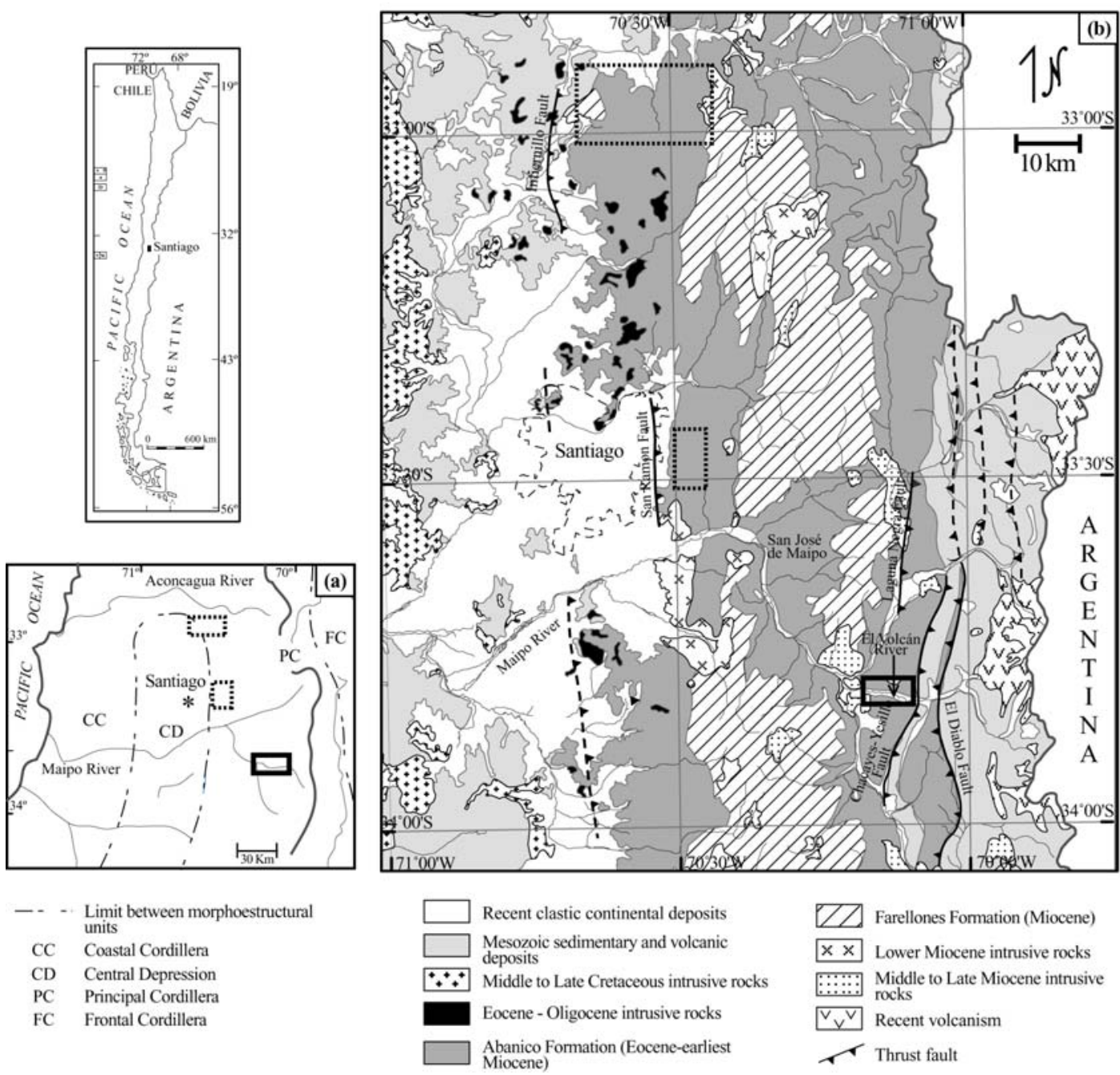

FIG. 1. Schematic morphoestructural and geologic maps of the Andean Cordillera in Central Chile. (a) main subdivisions and morphoestructural units according to Aubouin et al. (1973); (b) geologic map simplified and modified form Fock et al. (2005). Location of the studied area is indicated with a black rectangle, dashed line rectangles indicate the location of the Oligocene-lower Miocene volcaniclastic series of Chacabuco $\left(33.00^{\circ} \mathrm{S}\right)$ and Cerro Abanico $\left(33.30^{\circ}\right)$. 
paper is to present petrographic, mineralogical, geochronological $\left({ }^{40} \mathrm{Ar} /{ }^{39} \mathrm{Ar}\right.$ ages) and geochemical data (major, trace elements and $\mathrm{Sr}-\mathrm{Nd}$ isotopes) on the volcanic and related subvolcanic rocks from this formation in both cross-sections. These data have allowed to constrain the genesis of the rocks in
Abanico East formation. Moreover, the comparison with data of the Abanico West formation has provided an insight into the tectonic setting and arc magma genesis during late Eocene-Early Miocene in central Chile.

\section{GEOLOGICAL SETTING AND VOLCANIC STRATIGRAPHY}

At $33^{\circ} 50^{\prime} S$ central Chile the principal morphostructural units, from west to east, are: the Coastal Cordillera, Central Depression and Principal Cordillera (Fig. 1). The studied area is located in the Principal Cordillera, where a several kilometer thick sequence of sedimentary and volcanic rocks (Jurassic to Neogene in age) are present in a deformed belt. The Jurassic to Miocene units form a series of north-south trending belts which become progressively younger towards the west (Fig. 1). Near the Chilean-Argentinian border, the Mesozoic units consist of various marine and continental sedimentary and volcanic series that, from older to younger, correspond to the: Nieves Negras (Bathonian-early Callovian), Río Colina (CallovianOxfordian), Río Damas (Kimmeridgian), Lo Valdés (Tithonian-Hauterivian) and Colimapu (HauterivianAlbian) formations (see references in Charrier et al., 2002). The deposits of these units were formed during a subduction regime characterized by a magmatic arc in the Coastal Cordillera and a series of back-arc basins in the Principal Cordillera which were affected by marine transgressions and regressions (Mpodozis and Ramos, 1989; Vergara et al., 1995).

In the studied area the Abanico East formation is bounded on the east by the Colimapu Formation (Figs. 1 and 2) of Hauterivian-Albian age. The contact has been described either as a thrust fault (Thiele, 1980; Bustamante, 2001) or as concordant (González, 1963; Godoy et al., 1988). To the west, the deposits are bounded by the San Gabriel pluton with $\mathrm{K} / \mathrm{Ar}$ ages of $10.6 \pm 0.6$ (biotite), 11.6 \pm 0.2 (hornblende), and 13.9 $\pm 1.6 \mathrm{Ma}$ (plagioclase), errors at $2 \sigma$ level (Vergara and Drake, 1978; Drake et al., 1982), and one ${ }^{40} \mathrm{Ar} /{ }^{39} \mathrm{Ar}$ plateau age on biotite of $11.4 \pm 0.2 \mathrm{Ma}$ (error at $2 \sigma$ level; Kurtz et al., 1997). In the El Volcán area the Abanico East formation consists of a ca. 3,325 m thick series of volcanic and continental volcaniclastic rocks. Numerous dikes and sills cut this series, especially in the lower portions. They probably increase the estimated thickness. These subvolcanic bodies are possibly related to the magmatism that formed the lava flows from this formation.

At the Rodeo de los Bueyes area, between the Yeso River and the El Volcán River valley, Baeza (1999) carried out a stratigraphic and structural study of Abanico East formation. This author indicated that a west-vergent recumbent anticline affecting the strata of this formation is exposed there and that the volcanism changed with time, being of effusive character at the beginning, then mainly explosive, and finally effusive again. Two ${ }^{40} \mathrm{Ar} /{ }^{39} \mathrm{Ar}$ ages of $27.6 \pm 0.2$ and $25.6 \pm 0.2 \mathrm{Ma}(2 \sigma$ uncertainties) on plagioclase of tuffs at the middle level of the sequence were provided and interpreted as maximum ages by Baeza (1999). Unfortunately, neither age spectra nor analytical results were given by this author.

Abanico East formation volcanic and volcaniclastic series exposed in El Volcán area have a variable trend $\mathrm{N} 15-40^{\circ} \mathrm{W}$ and dip between 40 and $80^{\circ}$ to the southwest (Fig. 2). In the western part of the area, dips progressively decrease up to $16^{\circ}$ to the southwest. Two open folds are the main structures exposed, both occurring in the middle portion of the exposed series (Fig. 2).

The volcanic and volcaniclastic strata in the studied area are grouped here into four units on the basis of their lithologic features (Fig. 3); from older to younger they are: units I, II, III and IV. Unit I is made up of a 1,638 $\mathrm{m}$ thick series of basaltic and andesitic lava flows with intercalations of breccias (flow breccias, lahars, detrital flows and pyroclastic deposits) and volcaniclastic rocks. The lava flows are up to $14 \mathrm{~m}$ thick and have a massive bottom and central part and an amygdaloidal top. To the east 


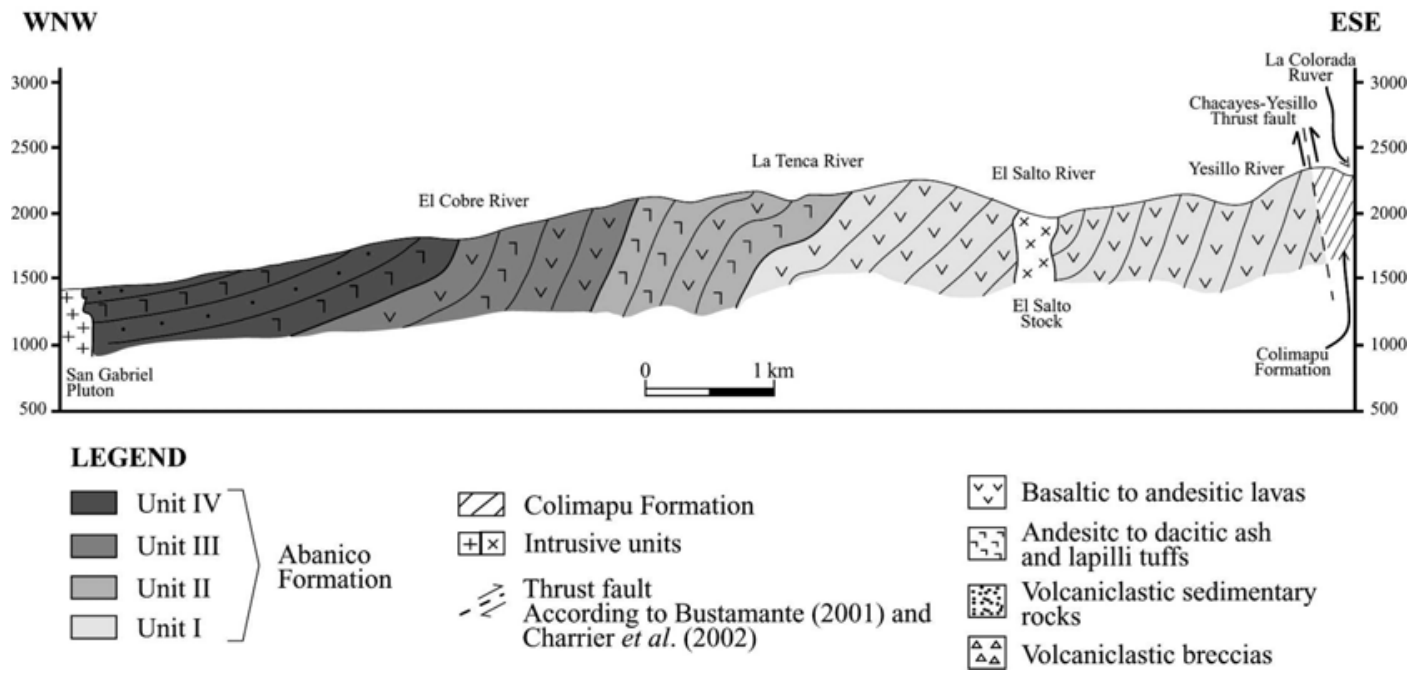

FIG. 2. Schematic WNW-ESE cross-section in the studied area (southern Volcán River valley) showing volcanic units defined in this work and their predominant lithology.

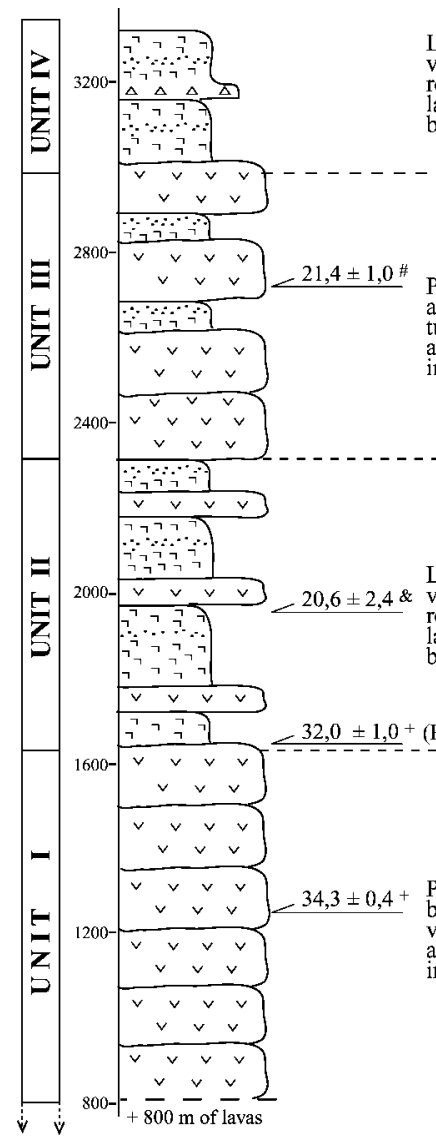

Lapilli and ash tuffs,

occaniclastic sedimentary

ocks; basaltic to intermediate avas and volcaniclastic

volcaniclastic sedimentary.

rocks, basaltic to intermediate

breccias intercalated. Poresites and andesites; nd sedimentary rocks

Porphyric basalts and

basaltic andesites;

volcaniclastic breccias

nd sedimentary rocks $\checkmark v$ Basaltic to andesitic lavas

$\neg\urcorner$ ᄀ Andesitc to dacitic ash

$\neg \neg \neg$ and lapilli tuffs

$\because$ Volcaniclastic sedimentary

rocks

\begin{tabular}{ll}
\hline$\Delta \Delta$ \\
$\Delta \Delta$
\end{tabular} Volcaniclastic breccias

${ }^{40} \mathrm{Ar} / 39 \mathrm{Ar}$ age in plagioclase (lava flows)

$+\quad$ Maximun age

\& Age based in one step

Plateau age

(RB) Age obtained in Rodeo de los Bueyes area, the rest of the ages are from El Volcán area.

FIG. 3. Stratigraphic column of the studied area. Location of analyzed samples used for geochronology are shown. 
this unit is bounded by a thrust fault in contact with the Colimapu Formation (according to Bustamante, 2001 and Charrier et al. , 2002). To the west Unit I is bounded by the La Tenca River where it conformably underlies Unit II (Fig. 2). Numerous basaltic to basaltic andesite sills and less abundant dikes, up to $12 \mathrm{~m}$ thick, are found in this unit and are possibly feeders of the lava flows. Unit I lithofacies correspond to proximal facies of stratovolcanoes.

Unit II corresponds to a ca. $683 \mathrm{~m}$ thick series mainly composed by andesitic ash tuffs, interpreted as ash-fall deposits, with intercalations of finely stratified volcaniclastic rocks of lacustrine origin and less abundant basic lava flows (Fig. 3). This unit conformably overlies and underlies units I and III, respectively, and their outcrops are distributed to the west of the La Tenca River (Fig. 2). Unit II lithofacies correspond to proximal lacustrine facies near volcanic centers.

Unit III is formed by a $664 \mathrm{~m}$ thick series of basic lava flows with intercalations of volcanic breccias (lahars, detrital flows and pyroclastic deposits) and finely stratified volcaniclastic rocks. This unit con- formably overlies and underlies units II and IV, respectively (Fig. 2). The lithology of this unit is similar to that of Unit I, the difference between both being the larger abundance of breccias and volcaniclastic rocks in Unit III. Unit III lithofacies correspond to proximal lacustrine facies near stratovolcanoes.

Unit IV is a $340 \mathrm{~m}$ thick series composed by fine andesitic ash-fall tuffs and lacustrine volcaniclastic rocks with intercalations of volcaniclastic breccias (pyroclastic flows) and basic lava flows. This unit conformably overlies Unit III and its outcrops extend to the east as far as near the El Cobre River. To the west, they are bounded by the San Gabriel pluton (Fig. 2).

All the rocks have been affected by very lowgrade non-deformative metamorphism in the prehnite-pumpellyite facies. Rocks around $500 \mathrm{~m}$ to the contact with the San Gabriel pluton show a strong alteration characterized by calcite and Fe-Ti oxides which partially to totally obliterate the primary textural and mineralogical features.

\section{PETROGRAPHY AND MINERAL CHEMISTRY}

The Abanico East formation is composed of three main lithologic types: basalt, basaltic andesite and andesite lava flows, volcaniclastic rocks and intrusive rocks represented by sills, dikes and stocks.

\section{BASALT, BASALTIC ANDESITE AND ANDESITE LAVA FLOWS}

Basaltic and basaltic andesite lava flows are porphyritic containing about 20 vol. \% phenocrysts of plagioclase, clinopyroxene, olivine pseudomorphs and Fe-Ti oxides, in a holocrystalline to hypocrystaline trachytic groundmass with similar mineralogy. Phenocrysts are typically $1-3 \mathrm{~mm}$ in size, although some plagioclase crystals are up to 1 $\mathrm{cm}$ in length. Apatite and minor zircon are common accessories. Andesite lava flows are relatively scarce in the stratigraphic column, occurring as intercalations between basalts and basaltic andesites in Units I and III (Fig. 3). They are porphyritic rocks containing phenocrysts of plagioclase and microphenocrysts of clinopyroxene in an intersertal groundmass composed by microlites of plagioclase and Fe-Ti oxides. The igneous paragenesis olivineplagioclase-clinopyroxene-Fe-Ti oxides suggests low pressures of crystallization of basaltic magmas (Gust and Perfit, 1987).

Plagioclase is the predominant and ubiquitous phase in all basalts and basaltic andesites and constitutes up to $90 \mathrm{vol} . \%$. Plagioclase phenocrysts commonly exhibit weak zoning and twins, and some display sieve texture. These phenocrysts are mainly labradorite, $\mathrm{An}_{70-50} \mathrm{Ab}_{30-48} \mathrm{Or}_{0-2}$ (Table 1), and they develop a weak normal zoning with change in composition of about $12 \%$ An. The groundmass microlites are labradorite-andesine (Table 1) and, for a same rock, microlites have lower An content than the phenocrysts. Thus, the compositional difference between phenocryst cores and microlites is of $3-35 \% \mathrm{An}$, whereas it is of $2-8 \%$ An between phenocryst rims and microlites.

Clinopyroxene is the second most abundant phase, although it is not present in all lavas, and has a modal abundance up to $15 \mathrm{vol} . \%$. Clinopyroxene 


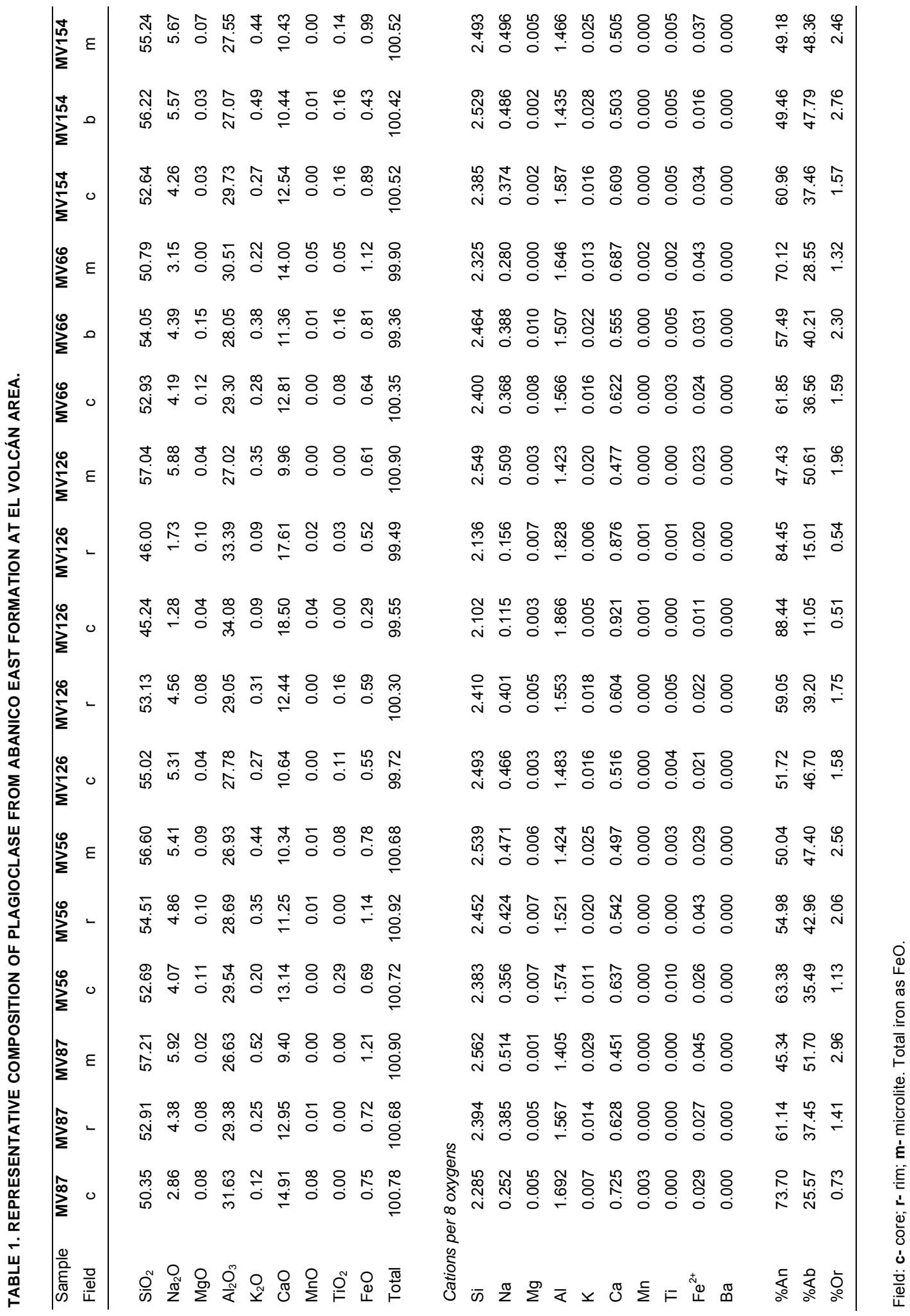




\begin{tabular}{|c|c|c|c|}
\hline 芯 & 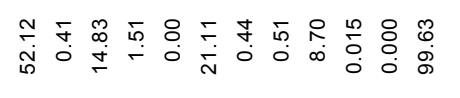 & 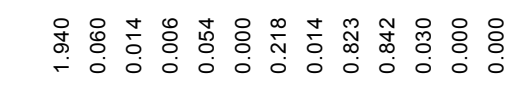 & 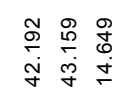 \\
\hline 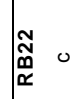 & 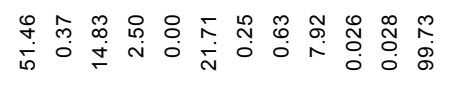 & 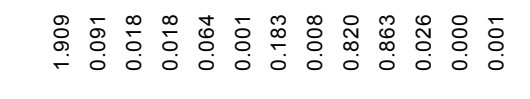 & 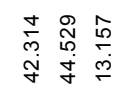 \\
\hline 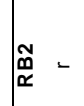 & 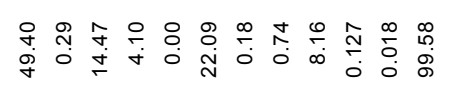 & 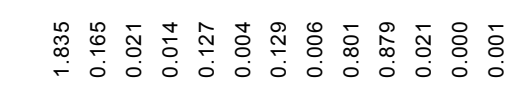 & 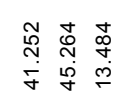 \\
\hline $\begin{array}{ll}\tilde{\tilde{w}} & 0 \\
\tilde{\alpha} & 0\end{array}$ & 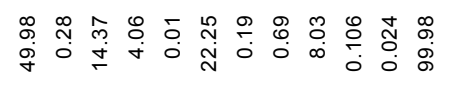 & 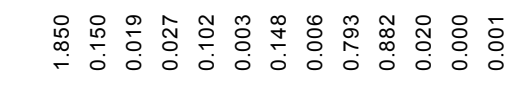 & 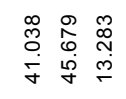 \\
\hline$\sum_{2}^{0} 0$ & 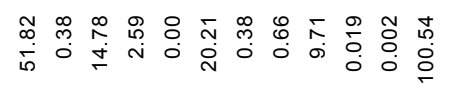 & 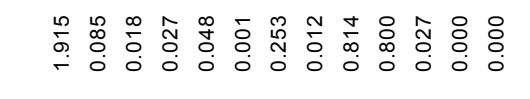 & 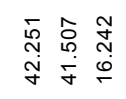 \\
\hline 焉 & 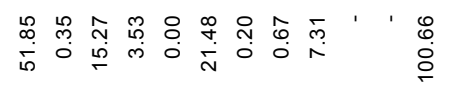 & 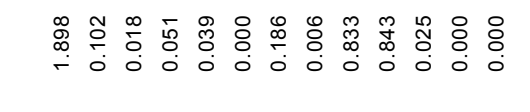 & 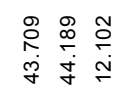 \\
\hline$\sum_{\sum}^{\mathbb{H}} \infty$ & 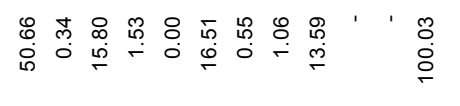 & 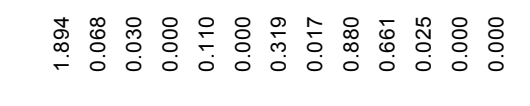 & 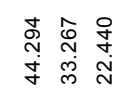 \\
\hline$\sum_{\Sigma}^{\stackrel{t}{n}}$ & 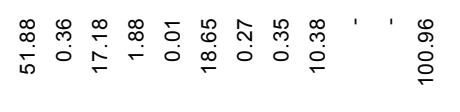 & 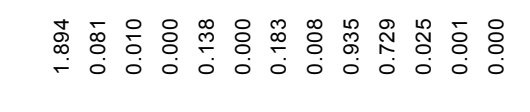 & $\begin{array}{lll}\infty & \infty & + \\
0 & 0 \\
0 & 0 & 0 \\
0 & 0 \\
0 & 0 & 0 \\
0 & 0 & 0\end{array}$ \\
\hline$\sum_{\substack{n\\
}}^{5} 0$ & 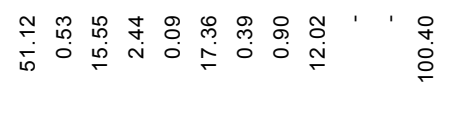 & 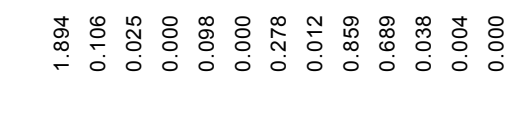 & 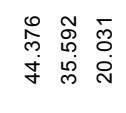 \\
\hline$\sum_{\Sigma}^{\infty} \sigma$ & 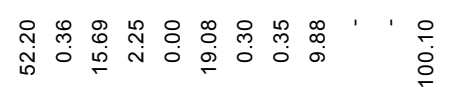 & 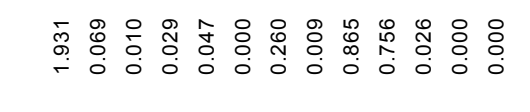 & 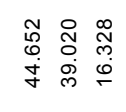 \\
\hline$\stackrel{\bigotimes}{\Sigma}-$ & 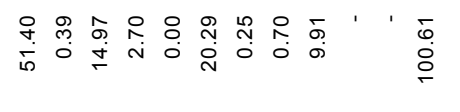 & 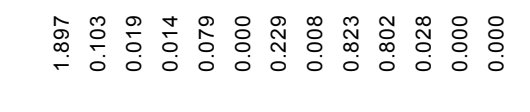 & 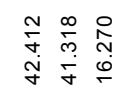 \\
\hline$\sum_{2}^{0} 0$ & 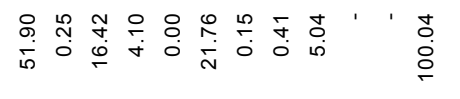 & 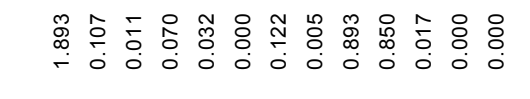 & 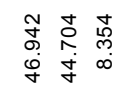 \\
\hline$\sum_{\substack{2 \\
\Sigma}}^{0} \sigma$ & 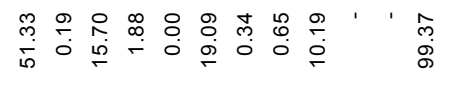 & 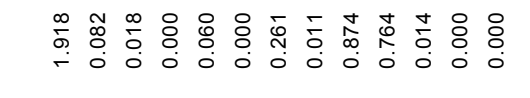 & 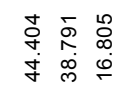 \\
\hline$\sum_{\substack{N \\
\Sigma}}^{\infty}$ & 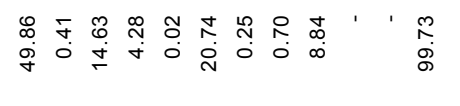 & 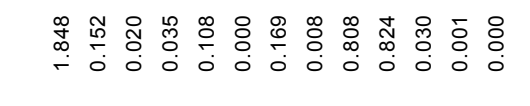 & 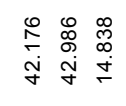 \\
\hline$\sum_{\substack{0 \\
2}}^{0} 0$ & 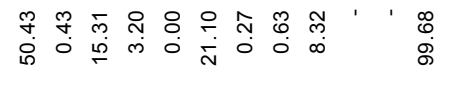 & 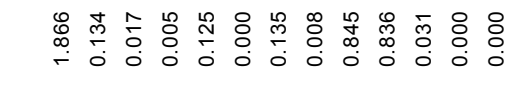 & 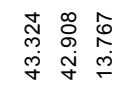 \\
\hline$\sum_{\substack{n \\
2}}^{0}$ & 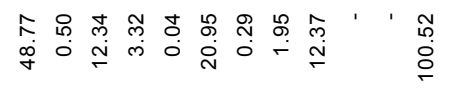 & 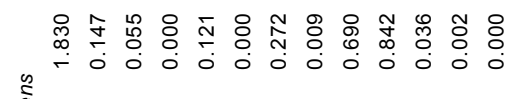 & 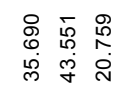 \\
\hline$\sum_{\substack{n \\
2}}^{0}$ & 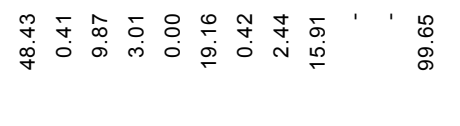 & 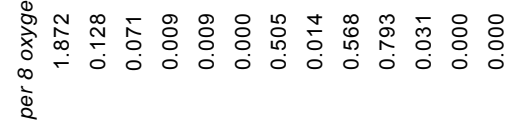 & 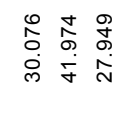 \\
\hline 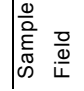 & 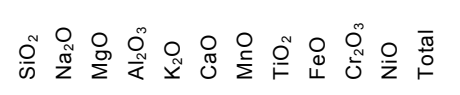 & 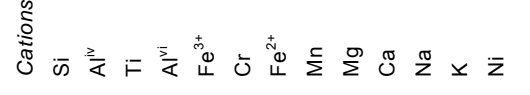 & 豆六峞 \\
\hline
\end{tabular}


phenocrysts are unzoned and correspond to augitediopside, $\mathrm{En}_{24-48} \mathrm{Wo}_{31-47} \mathrm{Fs}_{7-29}$ (Table 2). Groundmass clinopyroxenes are augite with higher Fe and lower $\mathrm{Ca}$ contents than the phenocrysts (Table 2). All phenocrysts have Ti contents $<0.07$ a.p.f.u (atoms per formula unit) which is characteristic of subalkaline rocks (Leterrier et al., 1982). They define a weak trend with a variable ratio of $\mathrm{Al}: \mathrm{Ti}$ a.p.f.u between $12: 1$ and $5: 1$, with a mean of $9: 1$. Clinopyroxenes from Unit III have the lower ratios $\mathrm{Al}: \mathrm{Ti}$, suggesting that they crystallized in magmas with a more calc-alkaline character that those associated to units I and II. In accordance with the $\mathrm{Al}$ and Ti contents, compositions of clinopyroxene phenocrysts overlap with $1 \mathrm{~atm}$ experimental compositions (see references in Stewart et al., 1996). Preliminary results of the application of the clinopyroxene-liquid geothermometer of Putirka et al. (1996) to clinopyroxene phenocrysts display crystallization temperatures between 1,000 and $1,120^{\circ} \mathrm{C}$.

Olivine phenocrysts occur as $2-3 \mathrm{~mm}$ subhedral pseudomorphs composed by smectite, iddingsite and Fe-Ti oxides. They have a modal abundance of up to 2 vol. \% and are consistently present in most of the lavas. Fe-Ti oxide phenocrysts are up to $2 \mathrm{~mm}$ in size and have a modal abundance about 5-10 vol.\%. Acicular apatite crystals of less than $0.1 \mathrm{~mm}$ in size are often found in the groundmass. Zircon crystals in the groundmass are more scarce and less than $0.1 \mathrm{~mm}$ in size.

\section{VOLCANICLASTIC ROCKS}

These rocks correspond to ash-fall pyroclastic deposits, pumice pyroclastic flows, detrital flows and lahars, which were deposited near stratovolcanoes in lakes and rivers. They originated by explosive volcanism and are represented by rocks of the medium and upper parts of the stratigraphic column (Fig. 3). The deposits are composed of 10 $\mathrm{cm}$ to $15 \mathrm{~m}$ thick reddish layers. Those fine-grained deposits show sedimentary structures like lamination, normal and inverse grading, and crossbedding, suggesting fall deposition in fluvial and/or lacustrine settings.

Ash tuffs correspond to pyroclastic fall and flow tuffs with andesitic to dacitic compositions. The pyroclastic fall tuffs, possibly plinian deposits, are found in up to $10 \mathrm{~m}$ thick layers and consist of ash, pumice and lapilli tuffs, formed by volcanic ash, fragments of pumice, crystals and crystal fragments, and lithic clasts. These latter are angular to subrounded with size ranging from $0.2 \mathrm{~mm}$ to $5 \mathrm{~cm}$ in diameter, and their lithology is characterized by porphyritic andesitic rocks with phenocrysts of plagioclase and fine ash tuffs. The crystals and crystal fragments are plagioclase of $0.1-4 \mathrm{~mm}$ in size. Fragments of pumice and volcanic ash have been commonly transformed into mafic phyllosilicates. The flow tuffs correspond to ignimbritic pyroclastic welded flows with a strong eutaxitic texture formed by abundant fragments of collapsed pumice.

The detrital flows and lahars are matrix-supported heterolithologic breccias of scarce abundance in the stratigraphic column (Fig. 3) occurring as up to $15 \mathrm{~m}$ thick layers without sedimentary structures. They are composed of crystals and crystal fragments of plagioclase, and angular to subangular lithic clasts, whose size varies from $6.4 \mathrm{~mm}$ to $20 \mathrm{~cm}$ in diameter consisting of porphyritic rocks with phenocrysts of plagioclase and, less abundant, fine-grained holocrystalline rocks. Components of the matrix have sizes below $4 \mathrm{~mm}$ and correspond to plagioclase crystals, lithic clasts of andesitic rocks, and interstitial fine volcanic ash.

\section{INTRUSIVE ROCKS}

The intrusive rocks are basaltic andesite to andesite sills, dikes and stocks. They are holocrystalline porphyritic rocks and contain about 10 vol. \% phenocrysts of plagioclase, clinopyroxene and amphibole (pargasite) in an intergranular groundmass. Plagioclase is the predominant and ubiquitous phase in all intrusives. Pargasite has a modal abundance of up to $10 \mathrm{vol} . \%$ and occurs only in these intrusive rocks.

\section{${ }^{40} \mathrm{Ar} /{ }^{39} \mathrm{Ar}$ AGES}

Four samples of basic lava flows were analyzed using plagioclase crystals. Their stratigraphic locations are shown in figure 3 . Detailed analytical data are given in table 3 and analytical methods are described in Apendix I. All the age spectra obtained show a saddle-shaped, more or less pronounced depending on the particular sample analysed. Several studies have indicated that this shape is the 
TABLA 3. DETAILED ${ }^{40} \mathrm{Ar} /{ }^{39} \mathrm{Ar}$ ANALYTICAL RESULTS OBTAINED ON LAVA FLOWS FROM ABANICO EAST FORMATION IN EL VOLCÁN AND RODEO DE LOS BUEYES AREAS.

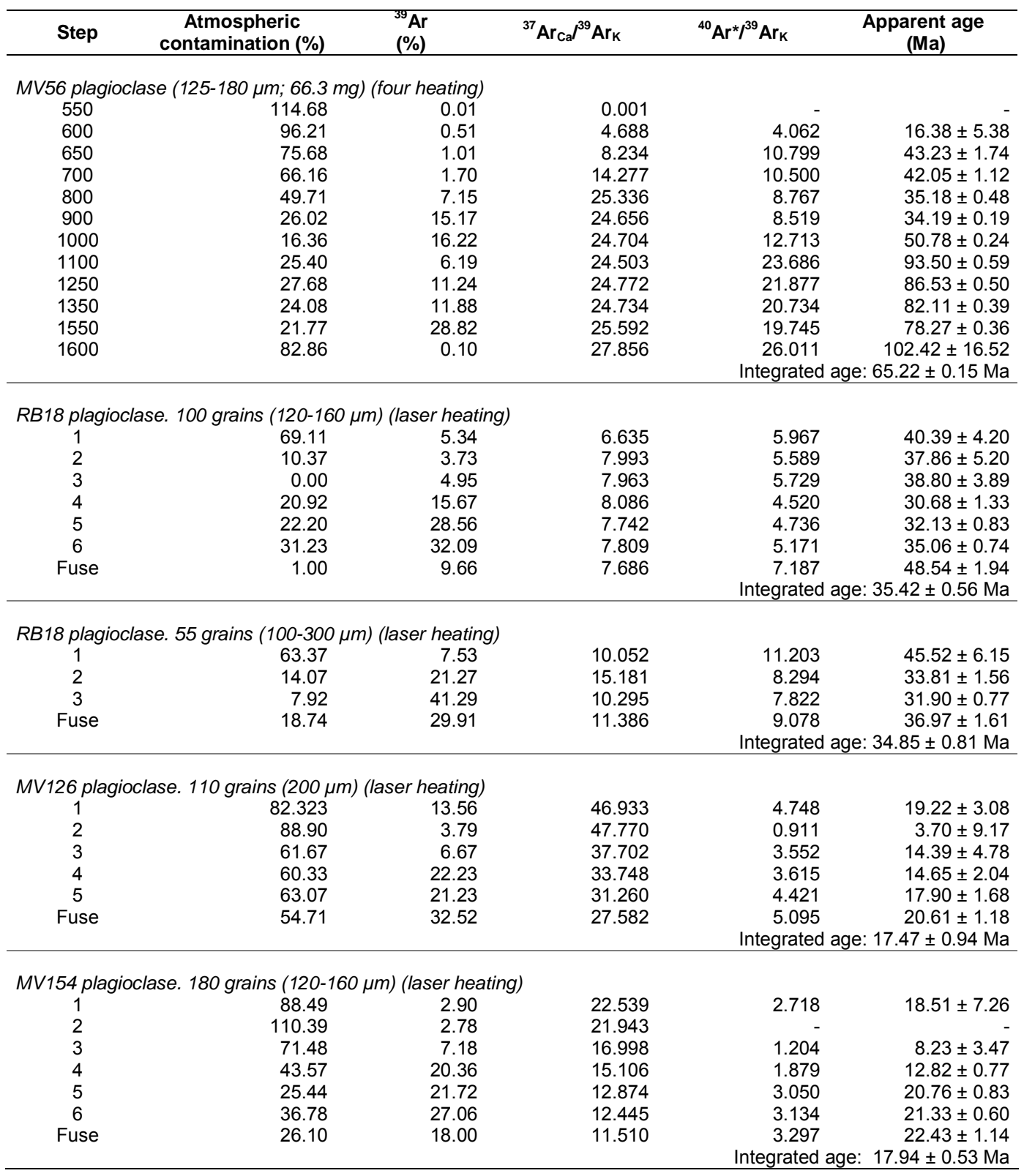

Step: temperature $\left({ }^{\circ} \mathrm{C}\right)$ or step number for the sample analysed with a furnace system or a laser probe, respectively. ${ }^{40} \mathrm{Ar} \mathrm{r}^{*}$ : radiogenic ${ }^{40} \mathrm{Ar}$. $\mathrm{Ca}$ and $\mathrm{K}$ : produced by $\mathrm{Ca}$ and $\mathrm{K}$ neutron interference, respectively. J: irradiation parameter. The error is at the $1 \sigma$ level and does not include the error in the value of the $\mathrm{J}$ parameter. Age calculations are made using the decay constants given by Steiger and Jäger (1977). Correction factors for interfering isotopes were $\left({ }^{39} \mathrm{Ar} /{ }^{37} \mathrm{Ar}\right)_{\mathrm{Ca}}=7.06 \times 10^{-4},\left({ }^{36} \mathrm{Ar} /{ }^{37} \mathrm{Ar}\right)_{\mathrm{Ca}}=2.79 \times 10^{-4}$ and $\left({ }^{40} \mathrm{Ar} /{ }^{39} \mathrm{Ar}\right)_{\mathrm{K}}=2.97 \times 10^{-2}$. 
result of excess argon (Kelley et al., 2002, and references therein), provided that the analysed plagioclases are compositionally homogeneous as it should be observed in the low variablility of the ${ }^{37} \mathrm{Ar}_{\mathrm{Ca}}{ }^{139} \mathrm{Ar}_{\mathrm{K}}$ ratio. According to these authors, the saddle-shape forms because the Ar released in the initial heating steps show old ages which decrease with progressive ${ }^{39} \mathrm{Ar}$ release, then approach the true age, and finally return to old ages at the end of the Ar release. Thus, the minimun age displayed in this kind of age spectrum corresponds to the age most proximal to the true age. This age is a maximun age.

The studied series has been affected by very low-grade metamorphism in the prehnite-pumpellyite facies for which a temperature range between 193 and $309^{\circ} \mathrm{C}$ has been estimated (Muñoz, 2005). McDougall and Harrison (1999) have estimated an isotopic closure temperature for plagioclase of 200$250^{\circ} \mathrm{C}$, which is fully enclosed in the temperature interval estimated for the metamorphic assemblages. Although the low precision of the temperature estimated for the metamorphism does not allow to establish whether the isotopic system was disturbed or not, previous studies on dating primary plagioclase from rocks under prehnite-pumpellyite facies show no evidence of disturbance of the plagioclase isotopic system (Aguirre et al., 1999; Fuentes, 2004). Thus, the interpretation of the age spectra must be viewed with cautious as the obtained apparent ages may indicate cooling, provided that the isotopic system has remained closed, or younging (or a mixing between the two) otherwise.

The plagioclase bulk sample from basalt MV56 displays an age spectrum characterized by a pronounced saddle-shape (Fig. 4). The lowest temperature steps, representing less than $3 \%$ of released ${ }^{39} \mathrm{Ar}$, show slightly high apparent ages, which can be explained by both excess argon and younger K-rich alteration phases. This is shown by the corresponding variable ${ }^{37} \mathrm{Ar}_{\mathrm{Ca}}{ }^{39} \mathrm{Ar}_{\mathrm{K}}$ ratios indicating that impure plagioclase was analyzed, because the ${ }^{37} \mathrm{Ar}_{\mathrm{Ca}}{ }^{139} \mathrm{Ar}_{\mathrm{K}}$ ratio is proportional to the $\mathrm{CaO} / \mathrm{K}_{2} \mathrm{O}$ ratio (with the relationship $\mathrm{CaO} / \mathrm{K}_{2} \mathrm{O}=2.179$ $\mathrm{x}^{37} \mathrm{Ar}_{\mathrm{Ca}}{ }^{139} \mathrm{Ar}_{\mathrm{K}}$, which was not specifically calibrated for the corresponding irradiations but was verified several times on several irradiations). Microprobe analyses of fresh plagioclase phenocrysts from sample (a) MV56 indicate that the almost constant ${ }^{37} \mathrm{Ar}_{\mathrm{Ca}}{ }^{139} \mathrm{Ar}_{\mathrm{K}}$ ratios between 24 and 28 , shown by the following temperature steps, correspond to fresh plagioclase. Two of these steps display concordant successive apparent ages, corresponding to the lowest apparent ages and to $22 \%$ of total released ${ }^{39} \mathrm{Ar}$. The weighted mean age of these two steps is $34.3 \pm 0.4 \mathrm{Ma}$. Finally, the last $75 \%$ of ${ }^{39} \mathrm{Ar}$ released show high apparent ages up to of $94 \mathrm{Ma}$. Despite the presence of excess argon in these plagioclase crystals, the authors consider the weighted mean age of $34.3 \pm 0.4 \mathrm{Ma}$ to estimate the maximum age of this rock because the gas released in both steps presents a minimum contribution of excess argon and/or radiogenic ${ }^{40} \mathrm{Ar}$ from younger K-rich alteration phases.

Two clusters of transparent plagioclase grains separated from the andesite RB18 display age spectra characterized also by a saddle-shape, although less pronounced than that of the sample (a) MV56 (Fig. 4). Thus, the low temperature steps, corresponding to $8-14 \%$ of released ${ }^{39} \mathrm{Ar}$, show slightly high apparent ages, followed by two low, concordant successive apparent ages at intermediate temperature, and then by slightly high apparent ages at high temperature, corresponding to $30-42 \%$ of released ${ }^{39} \mathrm{Ar}$. As in sample MV56, the intermediate temperature integrated ages have been considered as the estimate of the maximum age of this rock. Because both integrated ages are concordant at $2 \sigma$ level, the authors consider the weighted mean age of the integrated ages of the two analyses $(32.0 \pm 1.0 \mathrm{Ma})$ to be the best estimate of the maximum age. Furthermore, the ${ }^{37} \mathrm{Ar}_{\mathrm{Ca}}{ }^{39} \mathrm{Ar}_{\mathrm{K}}$ ratios between 8 and 15 are consistent with microprobe analyses on fresh plagioclase phenocrysts, showing that pure plagioclase was analyzed.

The cluster of transparent plagioclase grains separated from the basaltic andesite MV154 displays an age spectrum characterized by variable low apparent ages increasing at low temperature, followed by a relatively flat region of concordant apparent ages (Fig. 4). This region provides a plateau age of $21.4 \pm 1.0 \mathrm{Ma}$, corresponding to $67 \%$ of ${ }^{39} \mathrm{Ar}$ released. The ${ }^{37} \mathrm{Ar}_{\mathrm{Ca}}{ }^{39} \mathrm{Ar}_{\mathrm{K}}$ ratios regularly decrease with temperature (Fig. 4c), and the almost constant values of this ratio at the plateau region (between 13 and 12) compare well with those calculated from microprobe analyses. Compared with the plagioclases from samples (a) MV56 and (b) RB18, the existence of any excess argon at low temperatures is not clearly observed. 

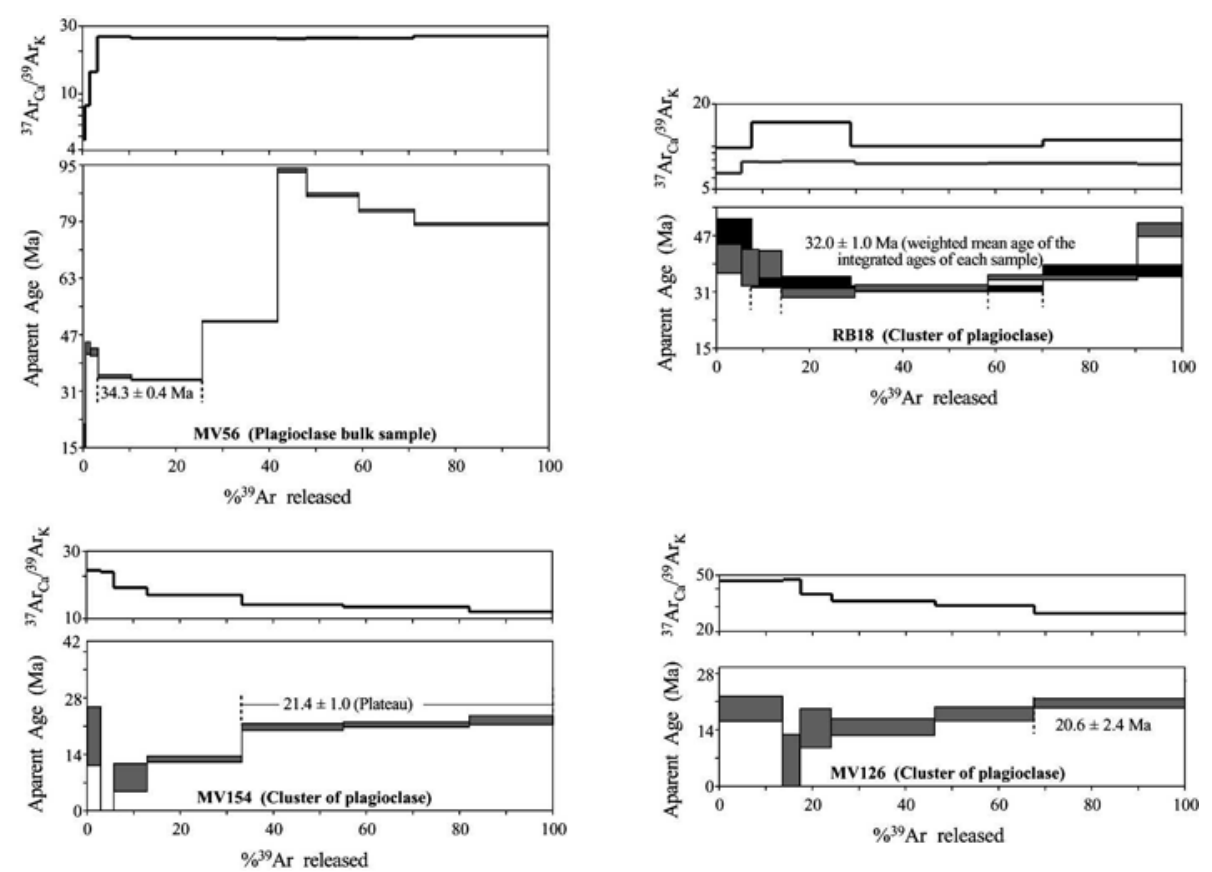

FIG. 4. ${ }^{40} \mathrm{Ar} /{ }^{39} \mathrm{Ar}$ and ${ }^{37} \mathrm{Ar}_{\mathrm{K}}{ }^{39} \mathrm{Ar} \mathrm{Ca}_{\mathrm{Ca}}$ ratio spectra obtained on plagioclase bulk samples from the studied area for samples (a) MV56; (b) RB18; (c) MV154 y (d) MV126.

The age spectrum shown by the cluster of transparent plagioclase grains separated from the basaltic andesite (d) MV126 is disturbed (Fig. 4d). Apparent ages at low temperature are variable, and are followed by regularly increasing apparent ages versus temperature up to a maximum of 20.6 \pm 2.4 Ma. Like the sample (c) MV154, the ${ }^{37} \mathrm{Ar}_{\mathrm{Ca}}{ }^{139} \mathrm{Ar}_{\mathrm{K}}$ ratios regularly decrease versus temperature (Fig. $4 d$ ), ranging from 47 to 28 . This last ratio agrees with that calculated from microprobe analyses and because the apparent age of this step is in agreement with the MV154 plateau age, the authors consider this high temperature age as being close to the true age.

\section{GEOCHEMISTRY}

A representative suite of 23 samples from the Abanico East formation and associated intrusives was selected for major and trace element analyses (Table 4). Seven samples were subsequently selected for $\mathrm{Sr}$ and $\mathrm{Nd}$ isotope analyses (Table 5). All samples have been affected by subgreenschist metamorphism, however their chemical composition did not appear to be significantly modified by secondary processes, although they show high loss of ignition (LOI), between 1.5-3.1 for lavas and subvolcanic intrusives, and 1.6-4.6 for tuffs (as is also the case for the Abanico West formation - e.g., Kay et al., 2005). Analytical methods are described in Apendix 1.

\section{MAJOR AND TRACE ELEMENT COMPOSITION}

Bulk compositions range from basalts to dacites with $\mathrm{SiO}_{2}$ contents between $47 \%$ and $70 \%$ (Fig. 5), though dacite compositions are only represented by tuffs. According to the $\left(\mathrm{Na}_{2} \mathrm{O}+\mathrm{K}_{2} \mathrm{O}\right)$ versus $\mathrm{SiO}_{2}$ relationship, all samples are sub-alkaline, except for three lavas from Unit I and one intrusive, which appear strongly affected by $\mathrm{Na}_{2} \mathrm{O}$ remobilization, as indicated by their albitized plagioclases. Consequently, the authors consider that all the samples of Abanico East formation belong to the sub-alkaline series. The most basic samples are found in Unit I. $\mathrm{K}_{2} \mathrm{O}$ versus $\mathrm{SiO}_{2}$ contents (Fig. 5) 
TABLE 4. CHEMICAL WHOLE ROCK ANALYSES OF VOLCANIC AND INTRUSIVE ROCKS FROM ABANICO EAST FORMATION AT EL VOLCÁN AND RODEO DE LOS BUEYES AREAS.

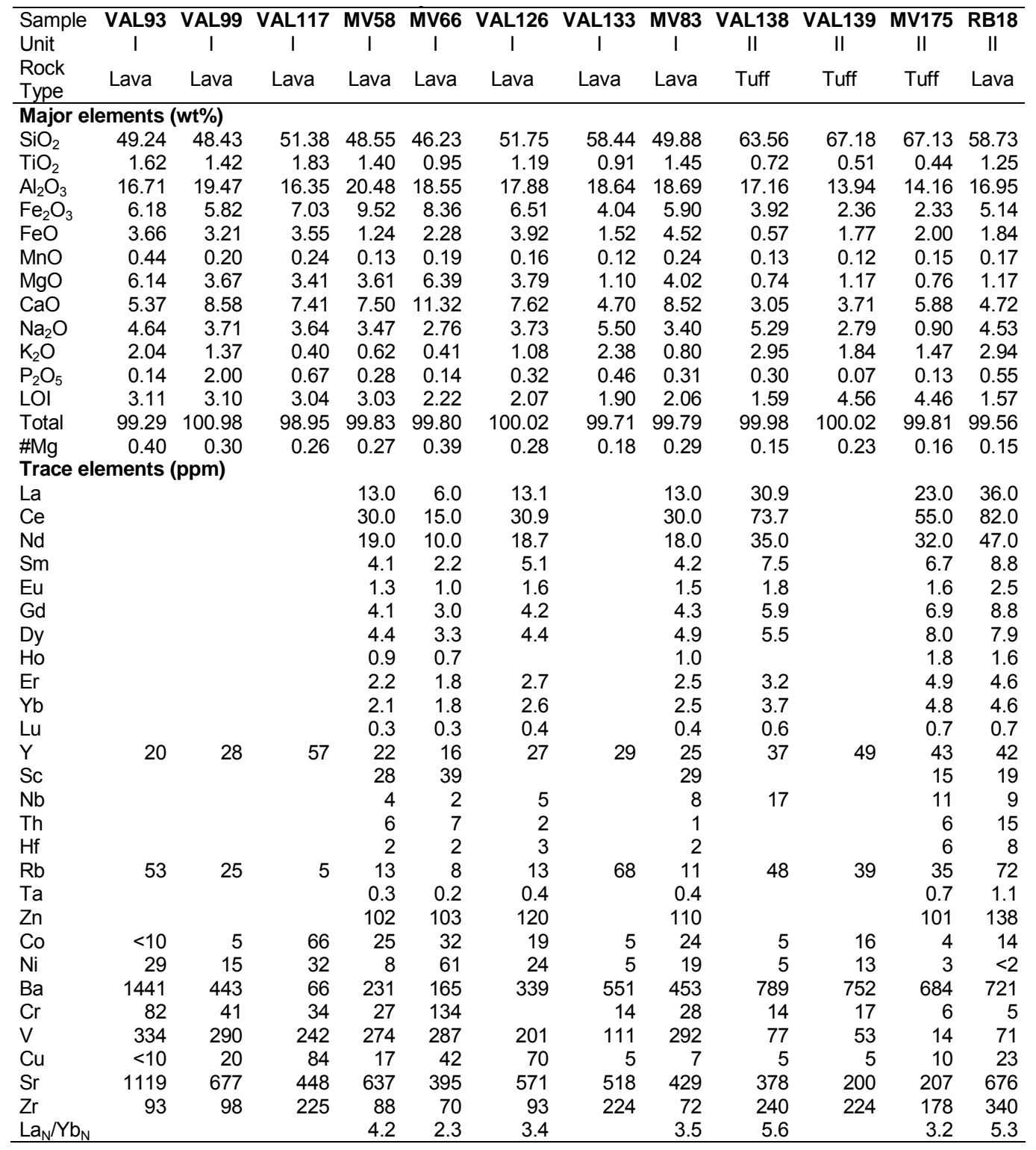

indicate that the rocks belong to a medium- $K$ to high- $K$ calc-alkaline series, in agreement with the AFM diagram (Fig. 6) where almost all samples plot in the calc-alkaline field. Furthermore, almost all basalts are $\mathrm{Al}_{2} \mathrm{O}_{3}$ rich (>19\%; see Table 4) and can be classified as high-Al basalts according to Middlemost (1975).

Major element variation is illustrated in figure 7 using $\mathrm{SiO}_{2}$ variation diagrams. In the basalt to andesite transition, $\mathrm{CaO}, \mathrm{MgO}, \mathrm{Al}_{2} \mathrm{O}_{3}, \mathrm{FeO}_{\text {total }}, \mathrm{TiO}_{2}$,
and\#Mg decrease with increasing $\mathrm{SiO}_{2}$ abundances, whereas $\mathrm{P}_{2} \mathrm{O}_{5}$ and $\mathrm{Na}_{2} \mathrm{O}$ increase. Data in these diagrams are slightly scattered, especially $\mathrm{TiO}_{2}$, $\mathrm{CaO}$ and $\mathrm{Na}_{2} \mathrm{O}$ abundances, possibly reflecting slight mobility during the processes of subgreenschist metamorphism (prehnite-pumpellyite facies). In the dacites, $\mathrm{CaO}$ and \# $\mathrm{Mg}$ increase, $\mathrm{MgO}$ and $\mathrm{FeO}_{\text {total }}$ contents are constant, and $\mathrm{Al}_{2} \mathrm{O}_{3}, \mathrm{TiO}_{2}$, $\mathrm{P}_{2} \mathrm{O}_{5}$, and $\mathrm{Na}_{2} \mathrm{O}$ abundances decrease as $\mathrm{SiO}_{2}$ increases. Variations of some trace elements with 
(tabla 4 continuación)

\begin{tabular}{|c|c|c|c|c|c|c|c|c|c|c|c|}
\hline $\begin{array}{l}\text { Sample } \\
\text { Unit } \\
\text { Rock } \\
\text { Type } \\
\end{array}$ & $\begin{array}{c}\text { VAL144 } \\
\text { II } \\
\text { Lava }\end{array}$ & $\begin{array}{c}\text { VAL149 } \\
\text { II } \\
\text { Lava }\end{array}$ & $\begin{array}{c}\text { VAL159 } \\
\text { II } \\
\text { Lava }\end{array}$ & $\begin{array}{c}\text { MV126 } \\
\text { II } \\
\text { Lava }\end{array}$ & $\begin{array}{c}\text { VAL163 } \\
\text { II } \\
\text { Lava }\end{array}$ & $\begin{array}{l}\text { MV154 } \\
\text { III } \\
\text { Lava }\end{array}$ & $\begin{array}{l}\text { RB9 } \\
\text { III } \\
\text { Lava }\end{array}$ & $\begin{array}{l}\text { RB17 } \\
\text { III } \\
\text { Lava }\end{array}$ & $\begin{array}{l}\text { MV60 } \\
\text { I } \\
\text { Stock }\end{array}$ & $\begin{array}{l}\text { RB22 } \\
\text { II } \\
\text { Stock }\end{array}$ & $\begin{array}{c}\text { VAL129 } \\
\text { I } \\
\text { Dike }\end{array}$ \\
\hline \multicolumn{12}{|c|}{ Major elements (wt\%) } \\
\hline $\mathrm{SiO}_{2}$ & 56.24 & 55.85 & 49.77 & 49.03 & 49.73 & 51.05 & 55.16 & 55.34 & 55.60 & 53.43 & 47.17 \\
\hline $\mathrm{TiO}_{2}$ & 1.35 & 1.34 & 1.21 & 1.22 & 1.26 & 1.16 & 0.89 & 1.20 & 0.90 & 1.08 & 1.30 \\
\hline $\mathrm{Al}_{2} \mathrm{O}_{3}$ & 17.09 & 16.62 & 18.07 & 19.91 & 17.36 & 19.65 & 18.45 & 16.99 & 18.67 & 18.93 & 19.05 \\
\hline $\mathrm{Fe}_{2} \mathrm{O}_{3}$ & 6.66 & 6.38 & 5.30 & 6.69 & 4.88 & 4.97 & 4.74 & 4.24 & 4.00 & 4.83 & 6.29 \\
\hline $\mathrm{FeO}$ & 1.35 & 1.60 & 4.32 & 3.60 & 5.15 & 3.88 & 3.44 & 4.71 & 3.68 & 4.68 & 5.38 \\
\hline $\mathrm{MnO}$ & 0.20 & 0.19 & 0.18 & 0.15 & 0.19 & 0.16 & 0.15 & 0.13 & 0.22 & 0.19 & 0.19 \\
\hline $\mathrm{MgO}$ & 1.60 & 1.56 & 4.07 & 3.48 & 5.09 & 3.15 & 1.62 & 3.01 & 2.42 & 3.72 & 4.07 \\
\hline $\mathrm{CaO}$ & 5.50 & 4.84 & 8.90 & 8.75 & 8.59 & 8.90 & 7.76 & 7.08 & 3.17 & 7.80 & 10.33 \\
\hline $\mathrm{Na}_{2} \mathrm{O}$ & 5.04 & 4.93 & 3.54 & 3.92 & 3.24 & 3.54 & 4.21 & 3.42 & 6.34 & 4.09 & 2.65 \\
\hline $\mathrm{K}_{2} \mathrm{O}$ & 1.30 & 2.24 & 0.94 & 0.96 & 1.08 & 1.25 & 1.46 & 1.69 & 1.92 & 0.86 & 0.85 \\
\hline $\mathrm{P}_{2} \mathrm{O}_{5}$ & 0.62 & 0.67 & 0.39 & 0.33 & 0.33 & 0.13 & 0.31 & 0.34 & 0.36 & 0.22 & 0.19 \\
\hline LOI & 2.72 & 2.45 & 1.63 & 1.73 & 2.34 & 1.86 & 1.73 & 1.51 & 2.70 & 2.47 & 2.17 \\
\hline Total & 99.67 & 98.67 & 98.32 & 99.77 & 99.24 & 99.70 & 99.92 & 99.66 & 99.98 & 102.30 & 99.64 \\
\hline \#Mg & 0.18 & 0.18 & 0.31 & 0.27 & 0.35 & 0.27 & 0.17 & 0.26 & 0.25 & 0.29 & 0.27 \\
\hline \multicolumn{12}{|c|}{ Trace elements (ppm) } \\
\hline $\mathrm{La}$ & & & 14.5 & 16.0 & & 19.0 & 21.0 & 21.0 & 20.0 & 15.0 & \\
\hline $\mathrm{Ce}$ & & & 32.3 & 35.0 & & 43.0 & 47.0 & 48.0 & 43.0 & 35.0 & \\
\hline $\mathrm{Nd}$ & & & 18.2 & 20.0 & & 23.0 & 25.0 & 24.0 & 25.0 & 20.0 & \\
\hline $\mathrm{Sm}$ & & & 5.0 & 4.0 & & 4.7 & 4.8 & 5.6 & 4.8 & 4.0 & \\
\hline Eu & & & 1.5 & 1.4 & & 1.6 & 1.5 & 1.5 & 1.6 & 1.3 & \\
\hline $\mathrm{Gd}$ & & & 4.0 & 4.3 & & 4.8 & 4.7 & 4.5 & 4.9 & 3.8 & \\
\hline Dy & & & 3.6 & 3.9 & & 4.3 & 4.3 & 4.2 & 4.4 & 3.7 & \\
\hline $\mathrm{Ho}$ & & & & 0.8 & & 0.8 & 1.0 & 0.8 & 1.0 & 0.8 & \\
\hline $\mathrm{Er}$ & & & 2.0 & 2.0 & & 2.2 & 2.6 & 2.1 & 2.7 & 2.0 & \\
\hline $\mathrm{Yb}$ & & & 2.1 & 2.0 & & 2.1 & 2.5 & 2.1 & 2.7 & 2.0 & \\
\hline Lu & & & 0.4 & 0.3 & & 0.3 & 0.4 & 0.3 & 0.4 & 0.3 & \\
\hline $\mathrm{Y}$ & 43 & 41 & 22 & 20 & 23 & 21 & 23 & 20 & 25 & 18 & 20 \\
\hline $\mathrm{Sc}$ & & & & 22 & & 22 & 18 & 26 & 12 & 23 & \\
\hline $\mathrm{Nb}$ & & & 4 & 4 & & 5 & 5 & 4 & 4 & 4 & \\
\hline Th & & & 3 & 5 & & 5 & 6 & 7 & 5 & 7 & \\
\hline $\mathrm{Hf}$ & & & 3 & 4 & & 3 & 6 & 6 & 5 & 2 & \\
\hline $\mathrm{Rb}$ & 22 & 43 & 16 & 15 & 40 & 18 & 37 & 47 & 46 & 15 & 19 \\
\hline $\mathrm{Ta}$ & & & 0.3 & 0.3 & & 0.3 & 0.4 & 0.5 & 0.3 & 0.3 & \\
\hline $\mathrm{Zn}$ & & & 76 & 92 & & 114 & 78 & 99 & 161 & 168 & \\
\hline Co & 5 & 5 & 21 & 22 & 35 & 17 & 15 & 25 & 11 & 25 & 66 \\
\hline $\mathrm{Ni}$ & 5 & 5 & 22 & 20 & 55 & 15 & $<2$ & 10 & $<2$ & 9 & 23 \\
\hline $\mathrm{Ba}$ & 552 & 1010 & 300 & 336 & 312 & 510 & 461 & 491 & 527 & 313 & 234 \\
\hline $\mathrm{Cr}$ & 13 & 16 & 39 & 26 & 80 & 41 & 10 & 204 & 9 & 24 & 31 \\
\hline V & 127 & 126 & 194 & 200 & 240 & 195 & 134 & 245 & 71 & 245 & 340 \\
\hline $\mathrm{Cu}$ & 5 & 5 & 23 & 26 & 15 & 34 & 6 & 56 & 20 & 116 & 18 \\
\hline $\mathrm{Sr}$ & 475 & 532 & 603 & 588 & 505 & 590 & 535 & 423 & 458 & 622 & 545 \\
\hline $\mathrm{Zr}$ & 228 & 228 & 92 & 124 & 116 & 160 & 154 & 171 & 164 & 130 & 69 \\
\hline$L a_{N} / Y b_{N}$ & & & 4.7 & 5.5 & & 6.2 & 5.7 & 6.7 & 5.0 & 5.0 & \\
\hline
\end{tabular}

LOI: loss of ignition at $950^{\circ} \mathrm{C} ; \mathrm{Mg}=\mathrm{MgO} / \mathrm{MgO}+\mathrm{FeO}_{\text {total }}$; for intrusives it is indicated the unit which they cut.

TABLE 5. Sr AND Nd ISOTOPE DATA OF VOLCANIC ROCKS FROM ABANICO EAST FORMATION AT EL VOLCÁN AND RODEO DE LOS BUEYES AREAS.

\begin{tabular}{|c|c|c|c|c|c|c|c|c|}
\hline $\begin{array}{l}\text { Unit } \\
\text { Rock Type }\end{array}$ & $\begin{array}{c}\text { MV-56 } \\
\text { I } \\
\text { B } \\
\end{array}$ & $\begin{array}{c}\text { MV66 } \\
\text { I } \\
\text { B } \\
\end{array}$ & $\begin{array}{c}\text { VAL126 } \\
\text { I } \\
A B \\
\end{array}$ & $\begin{array}{c}\text { MV83 } \\
\text { I } \\
\text { B } \\
\end{array}$ & $\begin{array}{c}\text { RB18 } \\
\text { II } \\
\text { A } \\
\end{array}$ & $\begin{array}{c}\text { VAL159 } \\
\text { II } \\
\text { B } \\
\end{array}$ & $\begin{array}{c}\text { MV126 } \\
\text { II } \\
\text { B } \\
\end{array}$ & $\begin{array}{c}\text { RB17 } \\
\text { III } \\
\text { AB } \\
\end{array}$ \\
\hline $\mathrm{Rb}(\mathrm{ppm})$ & 2 & 8 & 12.7 & 11 & 72 & 16.1 & 15 & 47 \\
\hline $\mathrm{Sr}(\mathrm{ppm})$ & 510 & 395 & 571 & 429 & 676 & 603 & 588 & 423 \\
\hline $\mathrm{Sm}(\mathrm{ppm})$ & 5.1 & 2.76 & 5.11 & 4.98 & 9.36 & 5.01 & 4.72 & 4.83 \\
\hline $\mathrm{Nd}(\mathrm{ppm})$ & 20.28 & 9.95 & 18.7 & 20.01 & 43 & 18.22 & 20.49 & 22.55 \\
\hline${ }^{87} \mathrm{Sr} /^{86} \mathrm{Sr}$ & 0.70380 & 0.70347 & 0.70378 & 0.70371 & 0.70388 & 0.70372 & 0.70372 & 0.70385 \\
\hline${ }^{143} \mathrm{Nd} / /^{144} \mathrm{Nd}$ & 0.51286 & 0.51290 & 0.51285 & 0.51284 & 0.51287 & 0.51289 & 0.51290 & 0.51285 \\
\hline${ }^{87} \mathrm{Sr}^{86} \mathrm{Sr}_{\mathrm{i}}$ & 0.70380 & 0.70345 & 0.70376 & 0.70368 & 0.70377 & 0.70369 & 0.70369 & 0.70374 \\
\hline${ }^{143} \mathrm{Nd} /{ }^{144} \mathrm{Nd}_{\mathrm{i}}$ & 0.51283 & 0.51287 & 0.51282 & 0.51281 & 0.51285 & 0.51286 & 0.51287 & 0.51283 \\
\hline$\varepsilon_{N d}$ & 4.4 & 5.2 & 4.1 & 4.0 & 4.7 & 5.0 & 5.2 & 4.4 \\
\hline
\end{tabular}

Rock type: B- basalt; AB- Basaltic andesite; A- andesite. Rates calculated with an age of $25 \mathrm{Ma} \cdot{ }^{87} \mathrm{Sr}^{66} \mathrm{Sr}_{\mathrm{i}}$ and ${ }^{143} \mathrm{Nd} /{ }^{144} \mathrm{Nd}$ correspond to the initial rates of $\mathrm{Sr}$ and $\mathrm{Nd}$, respectively. 


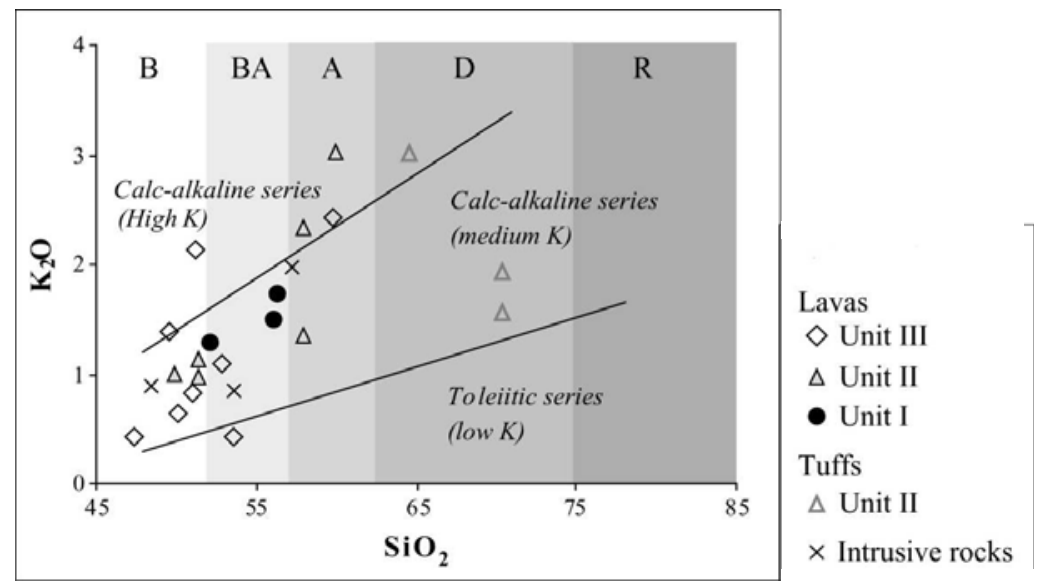

FIG. 5. $\mathrm{K}_{2} \mathrm{O}$ versus $\mathrm{SiO}_{2}$ plot, subdivisions between series after Le Maitre et al., 1989. B- basalt; AB- basaltic andesite; D- dacite; R- rhyolite.

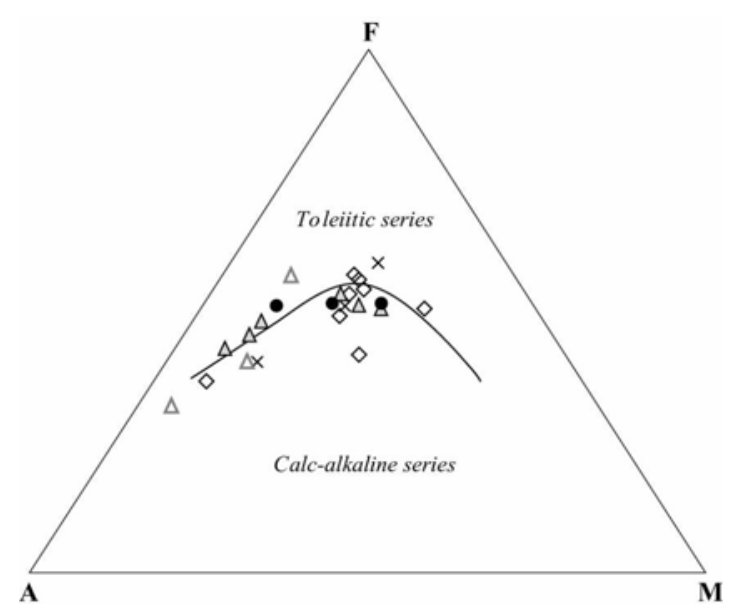

FIG. 6. AFM diagram [where $\mathrm{A}$ is $\mathrm{Na}_{2} \mathrm{O}+\mathrm{K}_{2} \mathrm{O}, \mathrm{F}$ is $\mathrm{FeO}_{\text {tot }}$ (total $\mathrm{Fe}$ as $\mathrm{FeO}$ ) and $\mathrm{M}$ is $\mathrm{MgO}$ ] showing samples from the studied area. Symbols as in figure 5 .

$\mathrm{SiO}_{2}$ are shown in figure $8 . \mathrm{Rb}, \mathrm{Ba}, \mathrm{Y}, \mathrm{Zr}$ and $\mathrm{Nb}$ contents display a positive correlation with $\mathrm{SiO}_{2}(\mathrm{Rb}$ and $\mathrm{Nb}$ not shown; see Table 4), while Sr, V and Sc show a negative correlation (Sc not shown; see Table 4). However, in the dacites, $\mathrm{Rb}, \mathrm{Ba}$ and $\mathrm{Zr}$ abundances tend to slightly decrease with increasing $\mathrm{SiO}_{2}$. Again, the scatter in the behaviour of these elements could reflect the mobility during processes of subgreenschist metamorphism. $\mathrm{Ni}, \mathrm{Cr}$ and $\mathrm{Co}$ abundances tend to decrease with increasing $\mathrm{SiO}_{2}$ up to close to $55 \% \mathrm{SiO}_{2}$ (Fig. 8; Co not shown; see Table 4). Samples with more than $55 \% \mathrm{SiO}_{2}$ have almost constant contents of these elements. Sample RB17 is an exception to the general trend of $\mathrm{Cr}$, showing a higher value of this element than all samples. The high $\mathrm{Cr}$ content for the sample RB17 could indicate accumulated olivine with inclusions of chromian spinel, which has not been observed in thin section.

The compositional trends displayed by basaltic to andesitic rocks are consistent with the fractionation of clinopyroxene, plagioclase, Fe-Ti oxides and olivine, mineral phases present in the mode of these rocks. In contrast, compositional trends shown by dacites indicate the strong influence of more sodic plagioclase and apatite removal. On the other hand, sample MV66 contains 134 ppm $\mathrm{Cr}$ and $61 \mathrm{ppm} \mathrm{Ni}$ at a \#Mg of 0.4 and $47 \% \mathrm{SiO}_{2}$, and represents the most primitive sample. However, these values of $\mathrm{Cr}$, $\mathrm{Ni}$ and \#Mg are very low and do not correspond to primary magmas, indicating that even the most primitive samples have already experienced fractionation of olivine and/or pyroxene. This conclusion agrees with Fuentes (2004), who indicated that the Abanico Formation does not display volcanic rocks with compositions of primary magmas.

The chondrite-normalized REE patterns of the basalts and basaltic andesites from the Abanico East formation (Fig. 9a, b) are similar in that they are enriched in light REE (LREE), with $(\mathrm{La} / \mathrm{Yb})_{\mathrm{N}}$ ranging between 2.3 and 6.7 and REE abundances varying between 8 and 64 times chondrite. The most primitive sample MV66 displays the lowest LREE contents and its pattern is the flatest. The REE patterns of the andesites and dacitic tuffs (Fig. 9c) are similar and parallel to those of the basalts and 

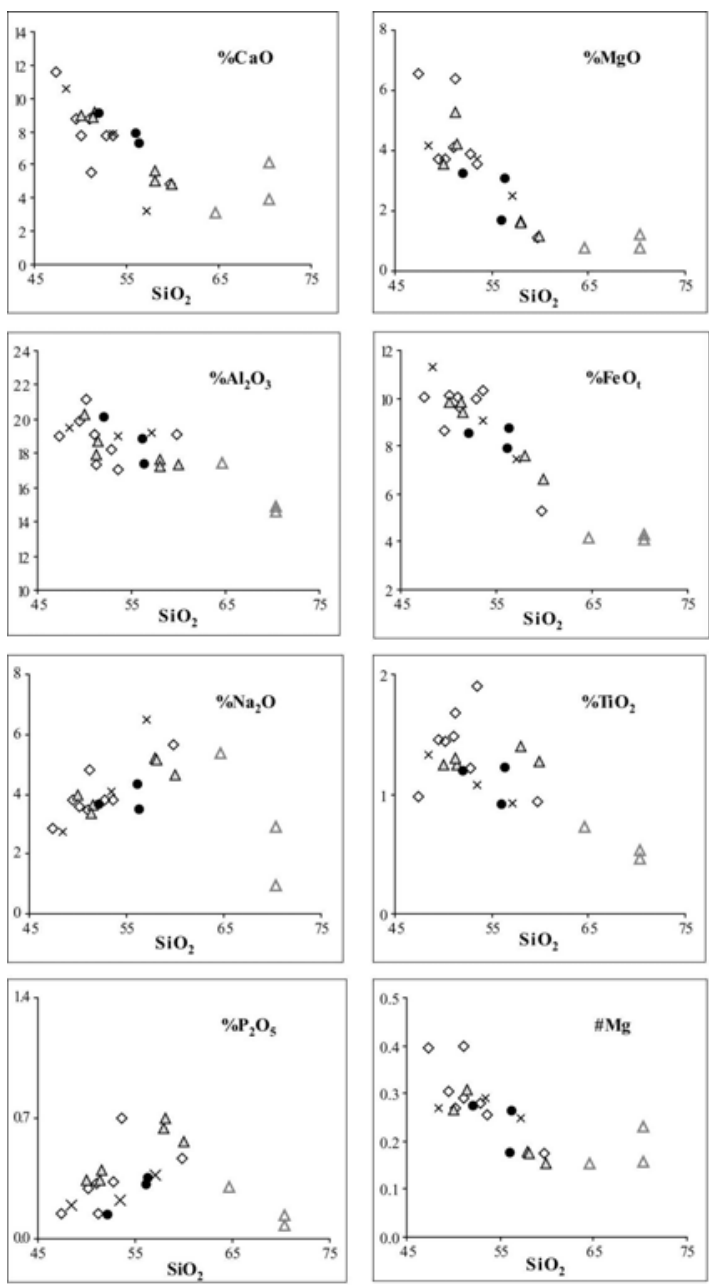

FIG. 7. Major element variation (versus $\mathrm{SiO}_{2}$ ) in the samples from the studied area. Symbols as in figure 5 .

basaltic andesites, and have $(\mathrm{La} / \mathrm{Yb})_{N}$ ratios between 3.2 and 5.6 and REE abundances in the range 12109 times chondrite. Although plagioclase is a significant fractionating phase, no pronounced negative Eu anomaly is observed (Fig. 9d). At similar HREE content, the basalts and basaltic andesites from the three lower units show a progressive enrichment in LREE from unit I to III. Thus, the $(\mathrm{La} / \mathrm{Yb})_{\mathrm{N}}$ ratios range between 2.2 and 3.9 for Unit I, from 4.1 to 5.5 for Unit II, and is of 5.8 for Unit III (Fig. 9e).

N-MORB normalized trace element plots (Fig. 10) display features considered typical of subductionrelated magmas (see, e.g., Pearce, 1982; McCulloch and Gamble, 1991): (a) enrichment in strongly incompatible large ion lithophile elements (LILE) such
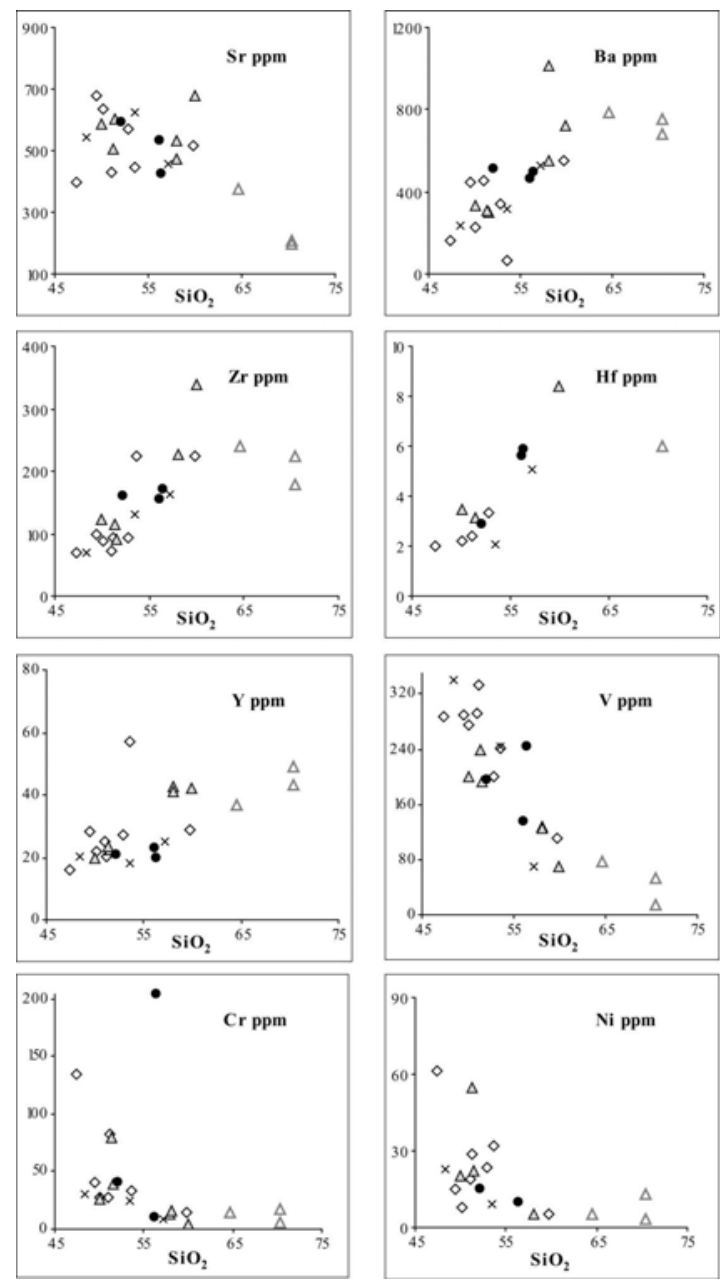

FIG. 8. Trace element variation (versus $\mathrm{SiO}_{2}$ ) in the samples from the studied area. Symbols as in figure 5 .

as $\mathrm{K}, \mathrm{Rb}$ and $\mathrm{Ba}$ relative to high field strength elements (HFSE), such as $\mathrm{Zr}, \mathrm{Hf}$ and $\mathrm{Ti}$, and LREE, and (b) prominent troughs at $\mathrm{Nb}$ and $\mathrm{Ta}$. Andesites and dacitic tuffs are more enriched in LILE than basalts and basaltic andesites. Sr contents are almost constant for all samples and Th abundances show a scatter not associated with the $\mathrm{SiO}_{2}$ content. Both elements are slightly mobile during alteration (see, e.g., Aguirre, 1988; Rollinson, 1993) and their contents should be considered with caution. The fact that Th shows a major variability in concentration than other mobile elements may well be the consequence of the low abundace of this element in the studied samples, which ranges between 7 and lower than $2 \mathrm{ppm}$, this last value corresponding to the detection limit for Th. Thus, even a slight proces- 

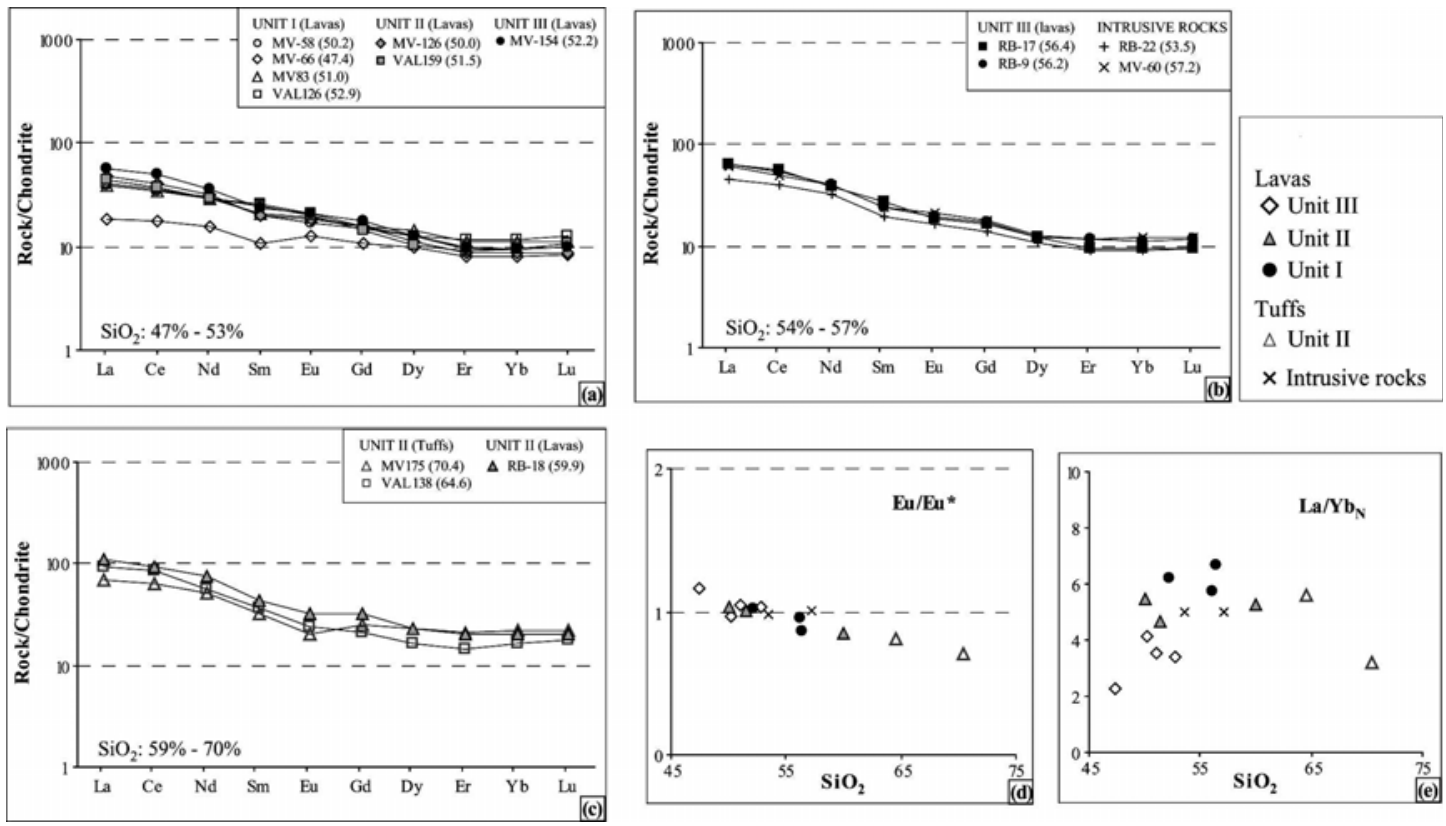

FIG. 9. Chondrite-normalized REE patterns $(a, b, c), \mathrm{La} / \mathrm{Yb}_{\mathrm{N}}(\mathrm{d})$ and $\mathrm{Eu} / \mathrm{Eu}^{*}$ ratios (versus $\left.\mathrm{SiO}_{2} ; \mathrm{e}\right)$ for the samples from the studied area. In the chondrite-normalized REE patterns samples are plotted by rock type. $\mathrm{SiO}_{2}$ contents (wt\%) of the samples in parentheses. Normalizing values from Nakamura (1974).
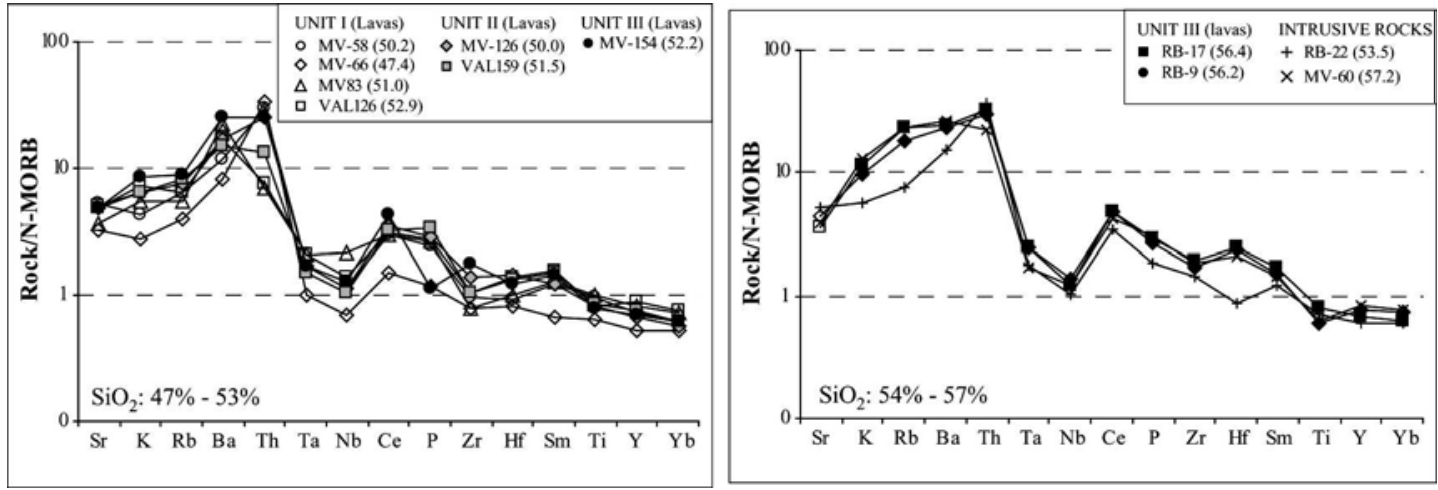

FIG. 10. N-MORB-normalized trace element diagrams for the samples from the studied area. Samples are plotted by rock type. $\mathrm{SiO}_{2}$ contents (wt\%) of the samples in parentheses. Normalizing values from Pearce (1983).

ses of alteration may have a large effect on Th concentrations without altering significatively other elements whose abundances are higher.

Tectonic discrimination diagrams are shown in Fig. 11. Like the N-MORB normalized trace element plots (Fig. 10), these diagrams suggest that Abanico East formation magmatism was essentially calcalkaline in a continental margin. In figue $11 \mathrm{a}$, a trend of increase in La from units I to III is observed, which is in agreement with the enrichment in LREE with time.

\section{Sr AND Nd ISOTOPES}

The initial ${ }^{87} \mathrm{Sr} /{ }^{86} \mathrm{Sr}$ ratios of Abanico East formation volcanic rocks are low and cover a narrow range (0.70345-0.70380; Table 5). The lowest and highest values are found in basalts from Unit I, indicating that apparently no correlation can be 

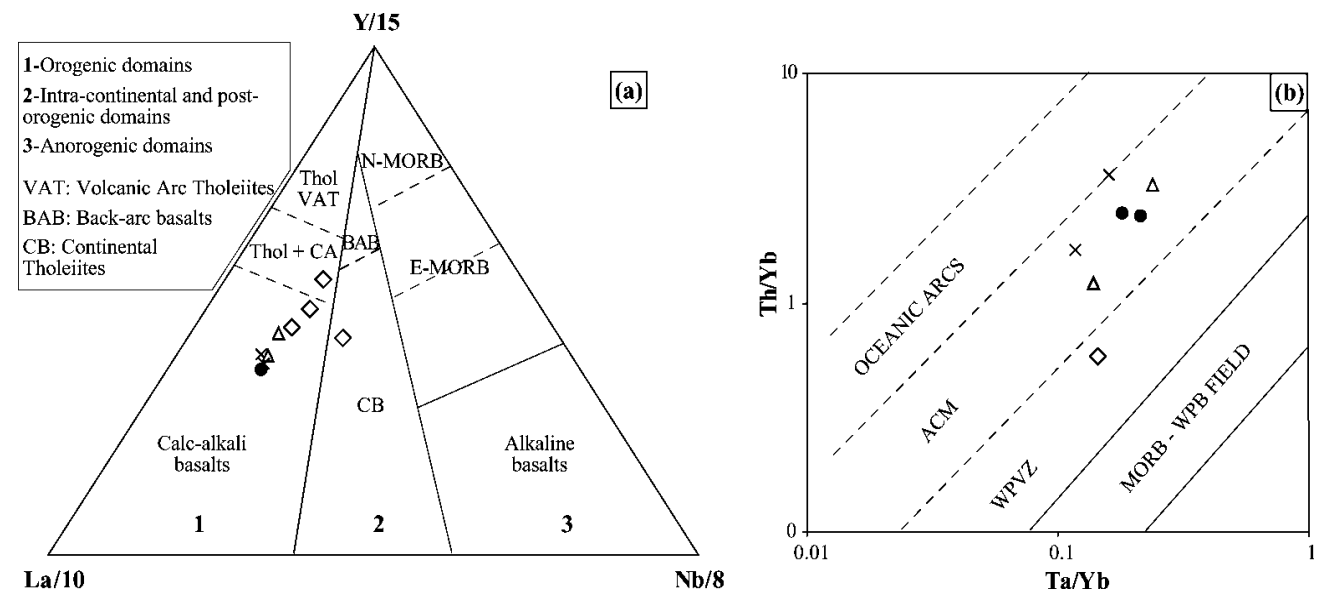

FIG. 11. Tectonic discrimination diagrams for (a) basic volcanic rocks (Cabanis and Lecolle, 1989) and (b) intermediate to acid volcanic rocks (fields taken from Gorton and Schandl, 2000). ACM- active continental margin; WPVZ- within plate volcanic zone; WPBwithin plate basalts. Symbols as in figure 9 .

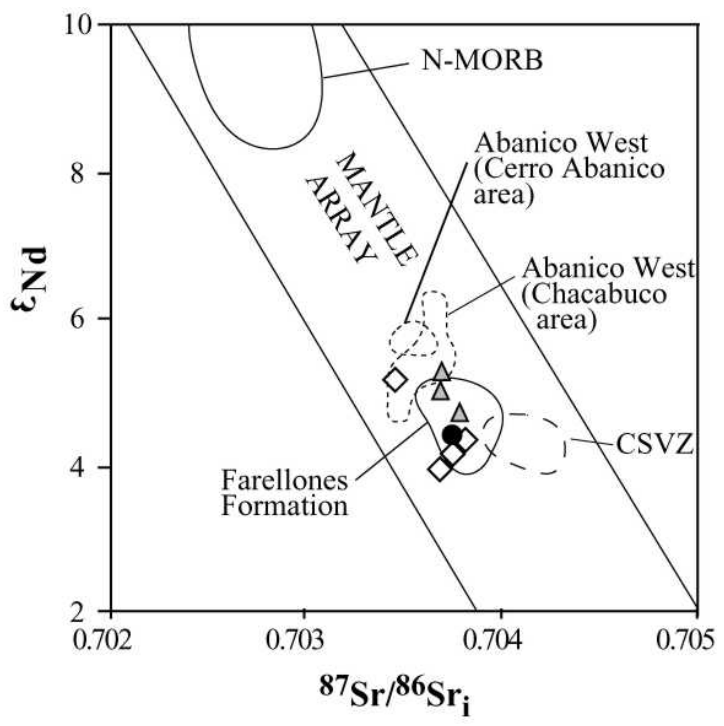

FIG. 12. $\varepsilon_{\mathrm{Nd}}$ values versus initial ${ }^{87} \mathrm{Sr} /{ }^{86} \mathrm{Sr}$ ratios for samples from the studied area. Location of samples with respect N-MORB, CSVZ and West Abanico formation at Chacabuco and Cerro Abanico areas (Nyström et al., 1993; Fuentes, 2004).

identified between initial ${ }^{87} \mathrm{Sr} /{ }^{86} \mathrm{Sr}$ ratios and $\mathrm{SiO}_{2}$ contents. In contrast, the initial ${ }^{87} \mathrm{Sr} /{ }^{86} \mathrm{Sr}$ ratios increase with increasing $\mathrm{Sr}$ (Table 5). The $\varepsilon_{\mathrm{Nd}}$ values of the analyzed samples range from +4.0 to +5.2 and do not correlate with the $\mathrm{SiO}_{2}$ contents. A slight negative correlation between $\varepsilon_{\mathrm{Nd}}$ values and initial ${ }^{87} \mathrm{Sr} /{ }^{86} \mathrm{Sr}$ ratios can be observed. On a $\varepsilon_{\mathrm{Nd}}$ versus initial ${ }^{87} \mathrm{Sr} /{ }^{66} \mathrm{Sr}$ ratio diagram (Fig. 12), all analyzed samples fall within the mantle array between the $\mathrm{N}$ -
MORB and the Central Southern Volcanic Zone (CSVZ) fields, with the most primitive sample MV66 plotting closer to N-MORB. In this diagram, the samples fall within the Farellones Formation field (Nyström et al., 1993) and are more enriched in radiogenic isotopes than other Oligocene-early Miocene volcanic rocks from the Abanico West formation (Nyström et al., 2003; Fuentes, 2004). 


\section{DISCUSSION}

In order to understand the evolution and petrogenesis of Abanico East formation volcanic and intrusive rocks it is necessary to determine if their bulk compositions represent melts. All samples contain up to $20 \mathrm{vol}$. $\%$ phenocrysts that do not show disequilibrium features with respect to the groundmass. As discussed above, these phenocrysts formed at low pressures and high-pressure remnants are not observed. Trends in major and trace element variation with increasing $\mathrm{SiO}_{2}$ suggest that fractional crystallization may be responsible for the compositional variations. Thus, the chemical composition of the samples would be related by fractionation, independently of the unit considered. Plagioclase, clinopyroxene, Fe-Ti oxides and olivine would have crystallizated from a primary magma.

\section{FRACTIONAL CRYSTALLIZATION}

Decrease in $\mathrm{MgO}, \mathrm{FeO}_{\text {total }}, \mathrm{Ni}, \mathrm{Cr}$ and Co contents with increasing $\mathrm{SiO}_{2}$ up to ca. $55 \% \mathrm{SiO}_{2}$ (Figs. 7 and 8 ) can be explained by significant fractionation of olivine and/or clinopyroxene. Decrease in $\mathrm{FeO}_{\text {total }}$ and $\mathrm{TiO}_{2}$ abundances with increasing $\mathrm{SiO}_{2}$ indicate fractionation of $\mathrm{Fe}-\mathrm{Ti}$ oxides. The ubiquitous and predominant occurrence of plagioclase in all samples suggests a significant fractionation of this phase, which would explain why $\mathrm{CaO}, \mathrm{Al}_{2} \mathrm{O}_{3}$ and $\mathrm{Sr}$ decrease and $\mathrm{Na}_{2} \mathrm{O}$ increases as $\mathrm{SiO}_{2}$ increases. The absence of negative Eu anomalies in almost all samples suggests that high oxygen fugacities were involved during the fractionation of plagioclase. Finally, the decrease in $\mathrm{P}_{2} \mathrm{O}_{5}$ and $\mathrm{Zr}$ abundances with increasing $\mathrm{SiO}_{2}$ in the dacites seems to indicate fractional crystallization of apatite and zircon in these more differentiated magmas.

The above inferences were used to model trace elements fractional crystallization in lavas from the Abanico East formation. The most primitive sample MV66 was considered as the parental composition for all samples. For samples with $\mathrm{SiO}_{2}$ contents between 50 and $53 \%$, the models acceptably reproduced the trace element abundances of the modelled daughter liquids (Table 6) from 55\% fractional crystallization of $44 \%$ plagioclase, $30 \%$ clinopyroxene, $20 \%$ olivine and $6 \%$ magnetite of the sample MV66. However, some trace elements were overestimated or underestimated, suggesting an open system behavior. Data for Th and, to a lesser extent, $\mathrm{Rb}, \mathrm{Ba}, \mathrm{La}, \mathrm{Sr}, \mathrm{Y}$ and $\mathrm{Yb}$ are not consistent with simple fractional crystallization models (Table 6). Small variations in the bulk distribution coefficients used in these models could explain the values of $\mathrm{Rb}, \mathrm{Ba}, \mathrm{La}, \mathrm{Sr}, \mathrm{Y}$ and $\mathrm{Yb}$. Differences in $\mathrm{Rb}$, Ba and La contents between the models and the samples increase from units I to III. As previously indicated, Th contents appear to be the result of mobility during alteration combined with its low abundance, which explains its inconsistent behavior with fractional crystallization models. For samples with $56 \% \mathrm{SiO}_{2}$, two parental compositions (samples MV66 and VAL159) were used for each model, because both compositions show and produce large differences in Th contents. Table 6 shows that, starting from MV66, it is possible to reproduce the trace element abundances of the modelled daughter liquids with $62 \%$ fractional crystallization of the assemblage $50 \%$ plagioclase, $30 \%$ clinopyroxene, $12 \%$ olivine and $8 \%$ magnetite. However, $\mathrm{Cr}$ and Th contents cannot be explained by this model. If sample VAL159 is considered as the parental composition, then $50 \%$ fractional crystallization of the same assemblage reproduces the daughter liquids, but again $\mathrm{Cr}$ is underestimated (Table 6).

\section{SOURCE COMPOSITION AND MELTING DEGREES}

To estimate degrees of partial melting the authors have used incremental, non-modal, batch melting models, in which melt is extracted at $0.1 \%$ increments, based on Bizimis et al. (2000). According to these authors, the results of incremental batch melting with increments of $0.1 \%$ or less are indistinguishable from those from a dynamic melting model. The trace element compositions of melts and solid residues were calculated using the nonmodal batch melting equations from Shaw (1970). Because none of the samples analyzed in this study represent true primary magmas, the effects of fractional crystallization cannot be excluded, and thus the bivariate plots of Pearce and Parkinson (1993) were used to examine these effects on the primary magma compositions obtained from the partial melting models. The models were based on melting a fertile MORB mantle (FMM) source in 
TABLE 6. FRACTIONAL CRYSTALLIZATION MODELS.

\begin{tabular}{|c|c|c|c|c|c|c|c|c|c|c|c|c|c|c|}
\hline \multicolumn{8}{|c|}{$\begin{array}{l}\text { Initial composition used in the fractional crystallization } \\
\text { models }\end{array}$} & & & & & & & \\
\hline & MV66 & VAL159 & & & & & & & & & & & & \\
\hline $\mathrm{Ba}$ & 165 & 300 & & & & & & & & & & & & \\
\hline $\mathrm{Rb}$ & 8 & 16 & & & & & & & & & & & & \\
\hline La & 6 & 14 & & & & & & & & & & & & \\
\hline $\mathrm{Sr}$ & 395 & 603 & & & & & & & & & & & & \\
\hline Th & 6.6 & 2.7 & & & & & & & & & & & & \\
\hline $\mathrm{Eu}$ & 1.0 & 1.5 & & & & & & & & & & & & \\
\hline Y & 16 & 22 & & & & & & & & & & & & \\
\hline $\mathrm{Yb}$ & 1.8 & 2.1 & & & & & & & & & & & & \\
\hline $\mathrm{Zr}$ & 70 & 92 & & & & & & & & & & & & \\
\hline Ta & 0.18 & 0.27 & & & & & & & & & & & & \\
\hline Co & 32 & 21 & & & & & & & & & & & & \\
\hline $\mathrm{Cr}$ & 134 & 39 & & & & & & & & & & & & \\
\hline $\mathrm{Ni}$ & 61 & 22 & & & & & & & & & & & & \\
\hline \multicolumn{15}{|c|}{ Fractional crystallization model for rock with $\mathrm{SiO}_{2}=50-53 \%$} \\
\hline \multicolumn{15}{|c|}{$\begin{array}{l}55 \% \text { fractional crystallization of parental composition MV66 } \\
\text { Assemblage: } 44 \% \mathrm{PI}, 30 \% \mathrm{Cpx}, 20 \% \mathrm{Ol} \text { and } 6 \% \mathrm{Mt}\end{array}$} \\
\hline & & $\mathrm{Ba}$ & $\mathrm{Rb}$ & La & $\mathrm{Sr}$ & Th & $\begin{array}{l}E \\
u\end{array}$ & $\mathrm{Y}$ & $\mathrm{Yb}$ & $\mathrm{Zr}$ & $\mathrm{Ta}$ & Co & $\mathrm{Cr}$ & $\mathrm{Ni}$ \\
\hline \multirow[t]{2}{*}{ Estimated } & Min & 314 & 17 & 13 & 508 & 14.0 & $\begin{array}{c}1 . \\
6\end{array}$ & 30 & 3.3 & 148 & 0.38 & 32 & 57 & 42 \\
\hline & Max & 204 & 16 & 10 & 223 & 13.1 & $\begin{array}{c}1 . \\
0\end{array}$ & 24 & 2.7 & 92 & 0.23 & 6 & 2 & 1 \\
\hline \multirow[t]{6}{*}{ Observed } & MV58 & 231 & 13 & 13 & 637 & 5.9 & $\begin{array}{c}1 . \\
3\end{array}$ & 22 & 2.1 & 88 & 0.31 & 25 & 27 & 8 \\
\hline & VAL126 & 339 & 13 & 13 & 571 & 1.5 & $\begin{array}{c}1 . \\
6\end{array}$ & 27 & 2.6 & 93 & 0.37 & 19 & - & 24 \\
\hline & MV83 & 453 & 11 & 13 & 429 & 1.4 & $\begin{array}{r}1 . \\
5\end{array}$ & 25 & 2.5 & 72 & 0.38 & 24 & 28 & 19 \\
\hline & VAL159 & 300 & 16 & 14 & 603 & 2.7 & $\begin{array}{r}1 . \\
5\end{array}$ & 22 & 2.1 & 92 & 0.27 & 21 & 39 & 22 \\
\hline & MV126 & 336 & 15 & 16 & 588 & 5.0 & $\begin{array}{c}1 \\
4\end{array}$ & 20 & 2.0 & 124 & 0.31 & 22 & 26 & 20 \\
\hline & MV154 & 510 & 18 & 19 & 590 & 5.0 & $\begin{array}{c}1 . \\
6\end{array}$ & 21 & 2.1 & 160 & 0.30 & 17 & 41 & 15 \\
\hline
\end{tabular}

Fractional crystallization model for rock with $\mathrm{SiO}_{2}=56 \%$

Assemblage: $50 \% \mathrm{Plg}, 30 \% \mathrm{Cpx}, 12 \%$ Ol, $8 \% \mathrm{Mt}$

\begin{tabular}{|c|c|c|c|c|c|c|c|c|c|c|c|c|c|c|}
\hline & & $\mathrm{Ba}$ & $\mathrm{Rb}$ & La & $\mathrm{Sr}$ & Th & $\begin{array}{l}E \\
u\end{array}$ & $\bar{Y}$ & $\mathrm{Yb}$ & $\mathrm{Zr}$ & $\mathrm{Ta}$ & Co & $\mathrm{Cr}$ & $\mathrm{Ni}$ \\
\hline \multicolumn{15}{|c|}{ Parental composition $\overline{\mathrm{MV} 66,62 \% \text { fractional crystallization }}$} \\
\hline \multirow[t]{2}{*}{ Estimated } & Min & 349 & 20 & 15 & 488 & 16.1 & $\begin{array}{c}1 . \\
8\end{array}$ & 34 & 3.7 & 172 & 0.45 & 39 & 47 & 51 \\
\hline & Max & 195 & 18 & 10 & 163 & 14.9 & $\begin{array}{r}0 . \\
8\end{array}$ & 26 & 2.9 & 83 & 0.20 & 4 & 1 & 1 \\
\hline \multicolumn{15}{|c|}{ Parental composition VAL $159,50 \%$ fractional crystallization } \\
\hline \multirow[t]{2}{*}{ Estimated } & Min & 513 & 31 & 27 & 701 & 5.1 & $\begin{array}{r}2 . \\
3\end{array}$ & 38 & 3.6 & 175 & 0.52 & 25 & 18 & 20 \\
\hline & Max & 338 & 29 & 21 & 319 & 4.8 & $\begin{array}{c}1 . \\
4\end{array}$ & 31 & 3.0 & 104 & 0.29 & 5 & 1 & 1 \\
\hline
\end{tabular}

Partition coefficients from the empirical values reported by Dunn and Sen (1994); Ewart and Griffin (1994); Fujimaki et al. (1984); Jefffries et al. (1995); Larsen (1979); Schock et al. (1979); Villemant et al. (1981). Concentration ranges are defined by the range of bulk partition coefficients possible for each element. 
spinel Iherzolite facies, because this source better fits chemical signatures. FMM represents the mantle source from which N-MORB is derived (Pearce and Parkinson, 1993). The modelled elements were: $\mathrm{Nb}$ and $\mathrm{Zr}$ (very highly incompatible or $\mathrm{VHI}$ ); $\mathrm{TiO}_{2}, \mathrm{Y}$ and $\mathrm{Yb}$ (highly incompatible or $\mathrm{HI}$ ); $\mathrm{CaO}, \mathrm{Al}_{2} \mathrm{O}_{3}$ and $\mathrm{V}$ (moderately incompatible or $\mathrm{MI}$ ); $\mathrm{MnO}, \mathrm{FeO}$ and Co (moderately compatible or $\mathrm{MC}$ ), and, $\mathrm{MgO}, \mathrm{Cr}$ and $\mathrm{Ni}$ (compatible or $\mathrm{C}$ ). Results indicate that magmas from Abanico East formation can be modelled by melting rates of about $12-18 \%$ of a $2 \%$ depleted FMM source but with re-enrichment of the very highly incompatible (VHI) elements.

\section{SLAB CONTRIBUTIONS VERSUS CRUSTAL CONTAMINATION ON THE COMPOSITION OF THE LAVAS}

As shown above, Abanico East formation volcanic and intrusive rocks have continental arc signatures. For instance, the analyzed samples show N-MORB normalized trace element plots (Fig. 10) typical of subduction-related magmas and tectonic discrimination diagrams (Fig. 11) indicate calc-alkaline affinities in a continental margin. Furthermore, the samples display some typical ratios of such a setting. Basalts and basaltic andesites have $\mathrm{Zr} / \mathrm{Y}>3, \mathrm{La} / \mathrm{Ta}>33$, and $\mathrm{Ba} / \mathrm{La}>18$, ratios for which values larger than 3,25 and 20 , respectively, have been described as characteristic of volcanic rocks formed in a continental arc margin (e.g., Pearce and Norry, 1979; Hickey et al., 1986; Hildreth and Moorbath, 1988; Kay and Kurtz, 1995).

Basalts are enriched in LILE, LREE and radiogenic isotopes relative to $\mathrm{N}-\mathrm{MORB}$ suggesting a more enriched mantle source than N-MORB. LREE over HREE enrichments are observed in basalts (Fig. 9), but this steepening of the REE pattern does not extend to the HREE which abundances remain relatively constant. Moreover, medium REE (MREE) are not strongly enriched relative to HREE. Both observations clearly argue against the role of garnet and amphibole in the source of the magmas. All basalts have HFSE abundances similar to those of N-MORB (Fig. 10), which can be considered as indicating a homogeneous mantle source for all volcanic rocks from Abanico East formation. This is in agreement with Nyström et al. (2003), who suggested a quite homogeneous source for the Abanico and Farellones formations.
The low pressure mineralogy in the basalts and the N-MORB like HFSE and Sr-Nd isotopes suggest a continental arc associated with a thinned crust during the formation and evolution of the magmas. Moreover, these chemical characteristics, and those described in previous sections, are similar to those present in lavas of the CSVZ which has evolved over a $30-35 \mathrm{~km}$ thick crust (Hildreth and Moorbath, 1988). Similar crustal thickness during the Late Eocene-early Miocene associated with the Abanico and Farellones formations have been suggested in other studies (Kay and Kurtz, 1995; Kay and Mpodozis, 2002; Charrier et al., 2002; Nyström et al., 2003; Fuentes, 2004; Kay et al., 2005).

There are some chemical differences between the units of the Abanico East formation established in this study. Both LILE and LREE abundances as well as $(\mathrm{La} / \mathrm{Yb})_{\mathrm{N}}$ ratios increase from units I to III. Because these rocks are all products of a convergent margin setting in which Nazca (Farallon) plate is subducting below the South American plate, these differences can be due to temporal changes in: (a) residence times in the crust, generating different levels of crustal contamination; (b) the geochemistry of slab input, and/or (c) the degree of partial melting. The absence of correlation between ${ }^{87} \mathrm{Sr} /{ }^{86} \mathrm{Sr}$ ratios and $\mathrm{SiO}_{2}$ contents argues against crustal contamination. Moreover, the extent of this possible contamination would have been small because the range of ${ }^{87} \mathrm{Sr} /{ }^{86} \mathrm{Sr}(0.70345-0.70380)$ and ${ }^{143} \mathrm{Nd} /{ }^{144} \mathrm{Nd}$ (0.51281-0.51287) initial ratios of the samples is only slightly different of that of typical island arc lavas (e.g., White and Patchet, 1984).

A decrease with time in the degree of partial melting could efficiently produce an increase of the LILE and LREE abundances. This would agree with Nyström et al. (2003) who suggested a decrease in the degree of partial melting during Oligocene-Early Miocene. However, such a decrease should also increase other incompatible elements, such as $\mathrm{Nb}$, $\mathrm{Ta}$ and $\mathrm{Zr}$, which is not observed in the analyzed samples. According to Hickey et al. (1986), lower degrees of partial melting of a homogeneous source with the same content of a refractory mineral phase retaining HFSE, would produce melts with larger LILE abundances and larger LILE/Nb ratios. This is observed in the samples of the Abanico East formation, but the presence of a mineral phase retaining HFSE in the mantle source is a debated issue.

Variations in LILE and LREE abundances in the 
Abanico East formation units can also be explained by changes in the geochemistry of slab fluid. LILE/ LREE ratios, such as $\mathrm{Ba} / \mathrm{La}, \mathrm{K}_{2} \mathrm{O} / \mathrm{La}$ and $\mathrm{Rb} / \mathrm{La}$ (Fig. 13), remain constant through the three lower units of the Abanico East formation, which suggest a homogeneous composition of slab fluid for all the magmatism that originated these volcanic rocks. In contrast, LILE/HFSE ratios, such as $\mathrm{Ba} / \mathrm{Nb}, \mathrm{K}_{2} \mathrm{O} / \mathrm{Nb}$ and $\mathrm{Rb} / \mathrm{Nb}$ (Fig. 13), increase from units I to III, suggesting higher contributions of a fluid derived from the subducted lithosphere with time.
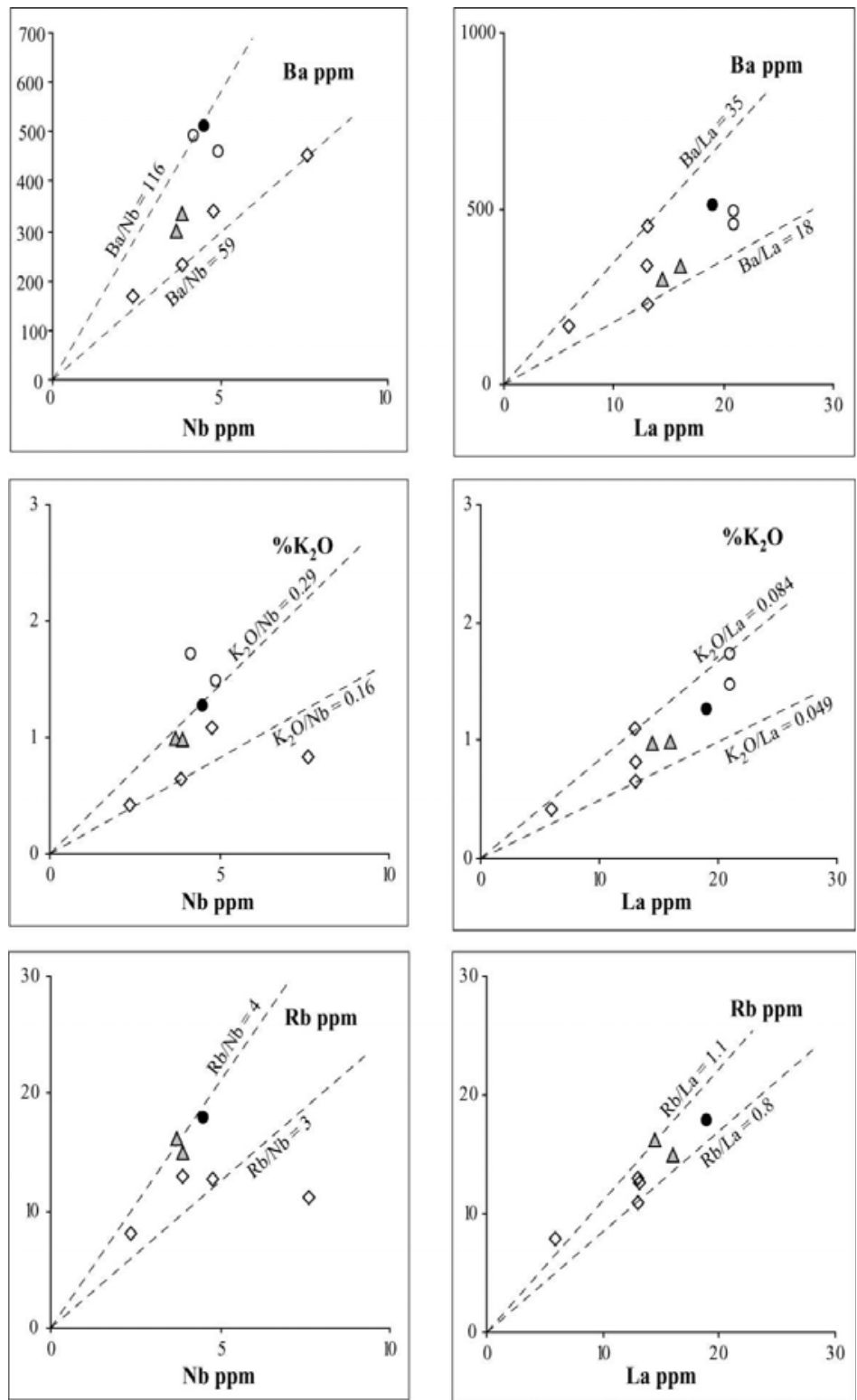

FIG. 13. LILE/HFSE and LILE/LREE trace element ratios variation between basalts and basaltic andesites from the three lower volcanic units. Symbols as in figure 9. Andesites from Unit III are indicated with an open circle. 


\section{GEOCHEMICAL COMPARISONS WITH OTHER CENOZOIC VOLCANIC DEPOSITS AND TECTONIC IMPLICATIONS}

In this section, the authors compare geochemical data of Abanico East formation in the El Volcán area with existing analyses of volcanic rocks from the Abanico West formation in two localities, in order to show east-west compositional variations across the Cenozoic arc. The two localities chosen are: (a) Chacabuco area, representing the western outcrops of the Abanico Formation at the northern end of the Central Depression, and (b) Cerro Abanico area, which corresponds to the type locality of the Abanico Formation (Fig. 1). From the first locality, the Chacabuco and Pocuro units (defined by Fuentes, 2004) with ages in the range of 29-28 and 23$21 \mathrm{Ma}$, respectively, have been used for comparison. From the Cerro Abanico area, the lower and upper members of the Abanico Formation (defined by Nyström et al., 2003) with ages between 31 and 25 and 25-22 Ma, respectively, have been selected. Outcrops from the localities of Chacabuco, Cerro Abanico and El Volcán are located at about 150, 160 and $190 \mathrm{~km}$ east from the actual trench, respectively. In Chacabuco and Cerro Abanico areas basic to intermediate lava flows are predominant and pyroclastic deposits and intercalations of volcaniclastic deposits are subordinate. The petrological studies in these two localities indicate that the volcanic rocks were formed in an active continental margin associated with an extensional regime in the arc (Nyström et al. , 2003; Fuentes, 2004). Crustal thickness was of the order of 30 to $35 \mathrm{~km}$, the inferred sources correspond to a fertile MORB mantle enriched in incompatible elements, and the magmas were possibly generated by partial melting degrees of $15-22 \%$ for the Chacabuco area and less than $15 \%$ for the Cerro Abanico area (Nyström et al., 2003; Fuentes, 2004).

The comparison between these three localities indicates that the Chacabuco area preferentially displays more basic compositions, mainly belonging to a tholeiitic series, whereas the Cerro Abanico and Río Volcán areas have volcanic rocks of the calc-alkaline series. $\mathrm{CaO}, \mathrm{MgO}, \mathrm{Cr}, \mathrm{Ni}$ and $\mathrm{Co}$ contents and $\mathrm{Mg} \#$ values are higher in the Chacabuco area than in the Cerro Abanico and Río Volcán areas, whereas $\mathrm{Na}_{2} \mathrm{O}$ and $\mathrm{TiO}_{2}$ abundances are lower. These chemical features indicate that the volcanic rocks from the Chacabuco area are less differentiated relative to the two eastern areas. LILE and HFSE contents display a slight increase from the west to east, i.e., from the Chacabuco area to Río Volcán area, whereas the Cerro Abanico area presents samples with LILE and HFSE contents between those of the other two localities (Fig. 14).

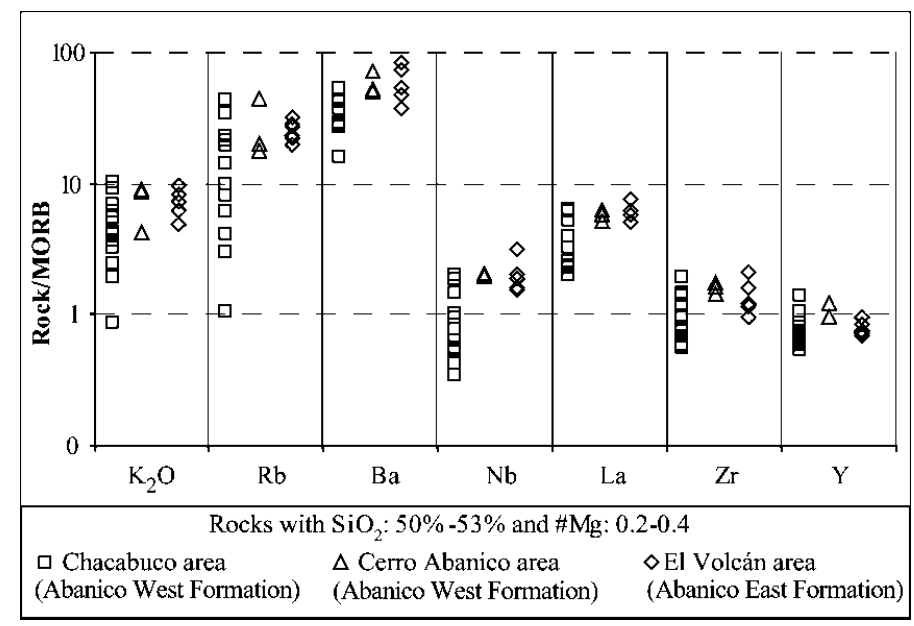

FIG. 14. Normalized concentrations for some trace element of the three compared localities. Normalizing values from Pearce and Parkinson (1993). 
Basalts and basaltic andesites $\left(\mathrm{SiO}_{2}=50 \%-53 \%\right.$; \#Mg=0.2-0.4) from the three localities show chondrite-normalized REE patterns that are relatively flat and parallel, enriched in LREE and have REE abundances that vary between 7 and 64 times chondrites. $(\mathrm{La} / \mathrm{Yb})_{\mathrm{N}}$ ratios increase from west to east due mainly to an increase in LREE, because at similar $(\mathrm{Sm} / \mathrm{Yb})_{\mathrm{N}}$ ratios, basalts and basaltic andesites show a progressive increase in $(\mathrm{La} / \mathrm{Sm})_{\mathrm{N}}$ ratios from the areas of Chacabuco to Cerro Abanico and to Río Volcán. These characteristics are the same in lavas of intermediate to felsic compositions. The initial ${ }^{87} \mathrm{Sr} /{ }^{86} \mathrm{Sr}$ ratios and $\varepsilon_{\mathrm{Nd}}$ values of the volcanic rocks in the three localities present a narrow range, falling within the mantle array between the N-MORB and the Central Southern Volcanic Zone (CSVZ) fields. As previously indicated, the Río Volcán samples are more enriched in $\mathrm{Sr}-\mathrm{Nd}$ isotopes than those from the other two areas (Fig. 12).

The chemical variations displayed by the volcanic rocks from the three localities can be the result of transverse variations inside a single arc or between an arc and backarc setting, considering a backarc setting as that imprinting an intraplate chemical signature in its volcanic products. According to the results of the present study, the geochemical characteristics of Abanico East formation volcanic rocks rather suggest an arc setting. Significant enrichments of incompatible elements that are typical of backarc settings are not observed in the Abanico East formation. For instance, $\mathrm{Zr} / \mathrm{Nb}$ ratios in samples from these volcanic rocks are not consistent with a backarc setting (Fig. 15), a similar situation found in rocks from the Chacabuco and Cerro Abanico areas.

Woodhead et al. (1993) and Pearce and Parkinson (1993) have indicated that depleted mantle sources for arc lavas are generally associated with the presence of an active backarc basin and that the depletion can be attributed to extraction of melt in the backarc basin prior to advection into the mantle wedge. $\mathrm{Ti} / \mathrm{Zr}$ and $\mathrm{V} / \mathrm{Ti}$ ratios can be used to infer the degree of depletion in mantle sources from which parental magmas to the lavas were derived (Woodhead et al., 1993). The samples of the three compared localities define narrow and similar ranges for these two ratios, arguing against different degrees of depletion from west to east, i.e., away from the trench, and supporting an homogeneous source for the three localities during late Eocene-early Miocene.

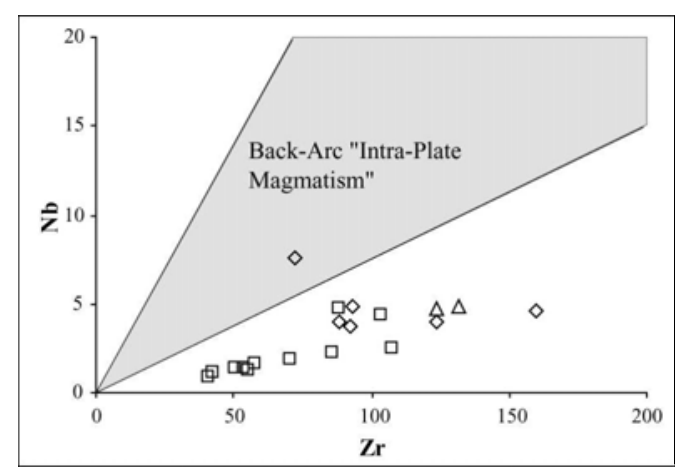

FIG. 15. Variation diagram of $\mathrm{Nb}$ versus $\mathrm{Zr}$ for basalts and basaltic andesites from the three localities, showing compositional field of intraplate rocks in back-arc settings for New Zealand and Patagonia (Tatsumi et al., 1995). Symbols as in figure 14 .

According to the above, transverse compositional variations between the three localities are the result of changes inside a single arc. These transverse variations are similar to those reported in other arcs of the world (e.g., Hickey et al., 1986, 1989; Tatsumi et al., 1991, 1995; Woodhead and Jonson, 1993; Barragan et al., 1998; Price et al., 1999; Stern, 2004). Consequently, these transverse compositional differences between the volcanic products of each locality can be due to decreases in the degree of partial melting, larger contributions of crustal material, progressive enrichment of the mantle wedge and/or decreases in the slab fluid influence from west to east, i.e., away from the trench. LILE/HFSE and LREE/HFSE ratios versus present trench distance are shown in figure 16 for the three localities, in order to analyze the contributions of a fluid derived from the subducted lithosphere. It is important to emphasize that during the late Eocene-Early Miocene, the trench may have been located more to the west than at present if the Chilean continental margin has been affected by subduction erosion (Stern, 1991, 2004; Kay and Mpodozis, 2002; Kay et al., 2005). The three compared localities define a slight decrease in LREE/HFSE and LILE/HFSE ratios from west to east, which is accompanied by slight increases in LILE and LREE abundances in the same direction. Similar patterns have been explained by Hickey et al. (1986) for present volcanoes in the SVZ as the resutlt of progressive enrichment of the mantle 
source and/or decrease of the degree of partial melting from west to east. Since the mantle source across the three localities appears as homogeneous, the transverse chemical variations are better explained by decreases in the slab fluid influence from west to east, probably resulting in lower degrees of partial melting.

On the other hand, $\mathrm{Nb} / \mathrm{Y}$ and $\mathrm{Zr} / \mathrm{Y}$ ratios can be used to investigate the mantle sources of the volcanic rocks without contamination by fluids from the subducting slabs. These ratios increase from west to east (Fig. 16) suggesting a decrease in the degree of partial melting. Lower degrees of partial melting toward the east is in agreement with values calculated for the three localities: $15-22 \%$ for Chacabuco area (Fuentes, 2004), <15\% for Cerro Abanico area (Nyström et al., 2003), and 12-18\% for Río Volcán area (this study).

In spite of the foregoing, assimilation processes of crustal materials cannot be discarded to explain these transverse variations, since the Río Volcán samples are more enriched in $\mathrm{Sr}-\mathrm{Nd}$ isotopes than
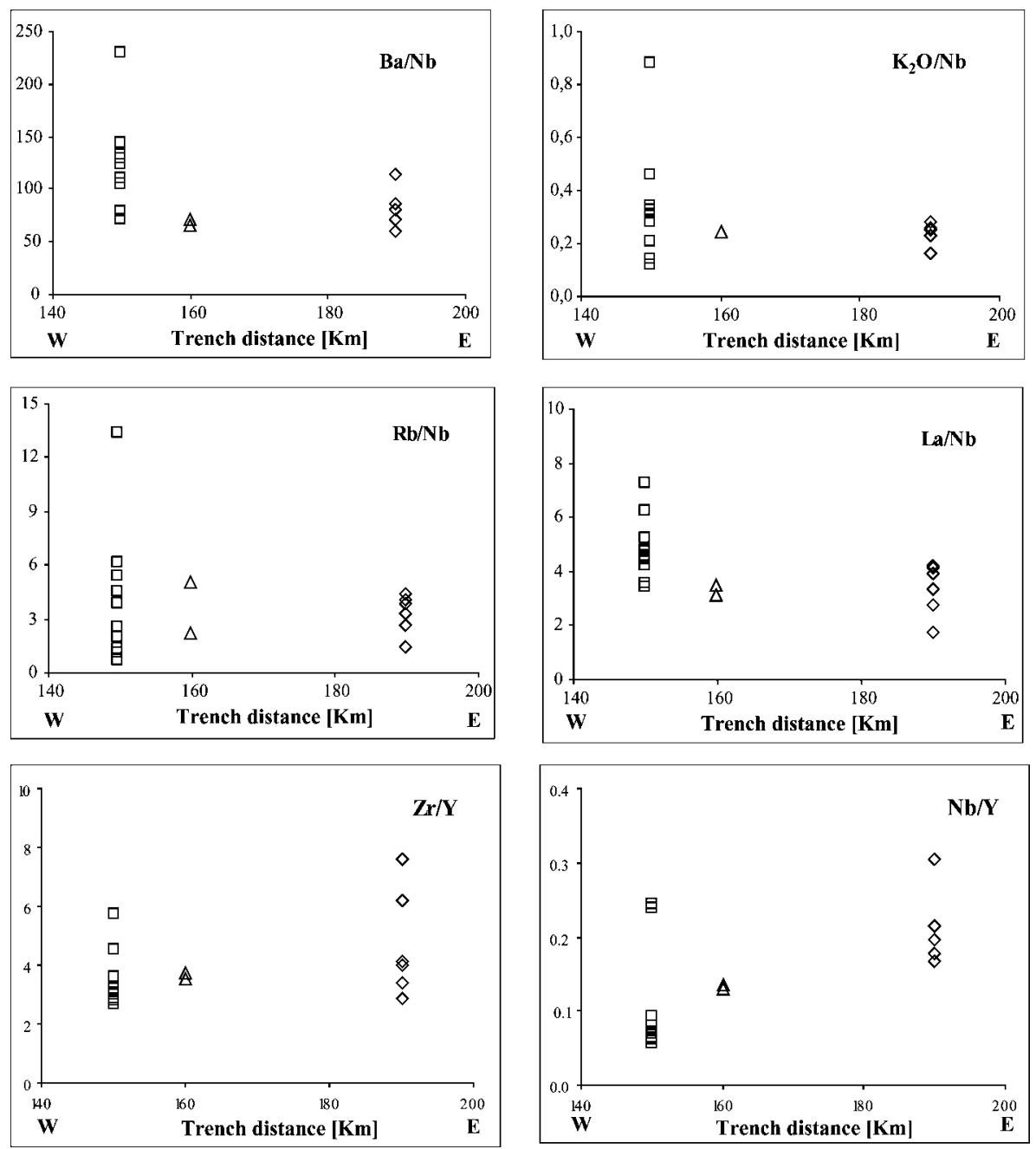

FIG. 16. Variation between trace elements ratios of LILE/HFSE, LREE/HFSE and between different compatibilities HFSE versus trench distance for basalts and basaltic andesites from the three localities. Symbols as in figure 14. 
those from the other two areas and more primitive compositions of the lavas are observed in the Chacabuco area. If the extent of assimilation was larger in the EI Volcán area, this could be associated to a larger crustal thickness there, which would produce lower degrees of partial melting. However, the decreases in LREE/HFSE and LILE/HFSE ratios from west to east cannot be explained by crustal contamination. Thus, the authors conclude that a combination of, at least, two processes were responsible for the transverse variations in the Cenozoic arc: a decrease in the slab fluid influence and an increase in the crustal contamination from west to east.

\section{CONCLUSIONS}

Petrographic and chemical study of Abanico East formation volcanic rocks exposed in the Andean Principal Cordillera, east of Santiago, suggest that a magmatic evolution dominated by plagioclase, clinopyroxene, olivine and magnetite was the most important control in the geochemical variations from basalt to dacite. Lavas from this series have a calcalkaline character and show chemical and isotopic characteristics typical of a subduction related volcanic arc developed in an active continental margin. Geochemical modelling suggests that the magmas of the Abanico East formation were generated by partial melting percentages around $12-18 \%$ of a spinel Iherzolite source.

Temporal chemical variation that develop through this series are an increase in LILE concentration and $\mathrm{La}_{\mathrm{N}} / \mathrm{Yb}_{\mathrm{N}}$, LILE/HFSE and LREE/ HFSE ratios. These variations are best explained by higher contributions of a fluid derived from the subducted lithosphere with time. The homogeneity in isotopic signature within the series argues against these temporal chemical variation being the result of a crustal contamination process.

The ${ }^{39} \mathrm{Ar} /{ }^{40} \mathrm{Ar}$ results suggest that the volcanism in the Abanico East formation series began at the most at $35 \mathrm{Ma}$ and lasted until about $21 \mathrm{Ma}$. A caution is that the subgreenschist metamorphism that affected these rocks could have also affected the Ar isotopic system, which together with the possible excess argon, question the reliability of the obtained ages. More information is needed on the maximum metamorphic temperatures in the region.

Chemical and isotopic comparison between lavas of Abanico East and Abanico West formations show that there are chemical variations between these series. These are represented by increased incompatible element concentrations, $\mathrm{La}_{\mathrm{N}} / \mathrm{Yb}_{\mathrm{N}}$ ratios and isotopic enrichment and a decrease in LILE/ HFSE and LREE/HFSE ratios from west to east, i.e., away from the trench. These variations are best explained by crustal contamination and lower contributions of a fluid derived from the subducted lithosphere in this same direction, possibly accompanied by a decrease in the degree of partial melting. Finally, because the Abanico West formation represents the volcanic front during the late Eocene-early Miocene (Kay and Mpodozis, 2002; Nyström et al., 2003; Fuentes, 2004;), the Abanico East formation should correspond to another volcanic chain, behind the Abanico West formation. Its higher crustal contamination suggests a larger crustal thickness away from the trench.

\section{ACKNOWLEDGEMENTS}

Economic support from the FONDECYT Project 1020809 and ECOS/CONICYT C03U01 are gratefully acknowledged. The authors thank ECOS-CONICYT 2003-2005 (MV and GF) which allowed academic interchange and the work in laboratories from the University of Nice, France. The authors are grateful to Dr. B. Levi (Stockholm, Sweden) for helpful comments and suggestions during the development of this work, and also to the reviewers Drs. S.M. Kay, E. Godoy and C. Stern. In addition, the authors thank Dr. R. Charrier and A. Fock (Universidad de Chile) for useful collaboration in the field work. 


\section{REFERENCES}

Aguirre, L. 1960. Geología de los Andes de Chile Central (Provincia de Aconcagua). Instituto de Investigaciones Geológicas, Boletín (9): 70 p. Santiago.

Aguirre, L. 1988. Chemical mobility during low-grade metamorphism of a Jurassic lava flow: Río Grande Formation, Perú. Journal of South American Earth Sciences 1: 343-361.

Aguirre, L.; Féraud, G.; Morata, D.; Vergara, M.; Robinson, D. 1999. Time interval between volcanism and burial metamorphism and rate of basin subsidence in a Cretaceous Andean extensional setting. Tectonophysics 313: 433-447.

Aubouin, J.; Borrello, A.V.; Ceccioni, G.; Charrier, R.; Hotin, P.; Frutos, J.; Thiele, R.; Vicente, J.C. 1973. Esquisse paléogéographique et structurales des Andes Méridioneles. Revue de Géographique Physique et Géologie Dynamique 15 (1-2): 11-72.

Baeza, O. 1999. Análisis de litofacies, evolución depositacional y análisis estructural de la Formación Abanico en el área comprendida entre los ríos Yeso y Volcán, Región Metropolitana. Thesis (Unpublished), Universidad de Chile, Departamento de Geología: 120 p. Santiago.

Barragan, R.; Geist, D.; Hall, M.; Larson, P.; Kurz, M. 1998. Subduction controls on the compositions of lavas from the Ecuadorian Andes. Earth and Planetary Science Letters 154: 153-166.

Bevins, R.E.; Robinson, D.; Aguirre, L.; Vergara, M. 2003. Episodic burial metamorphism in the Andes-A viable model?. Geology 31: 705-708.

Bizimis, M.; Salters, V.J.M.; Bonatti, E. 2000. Trace and REE content of clinopyroxenes from supra-subduction zone peridotites. Implications for melting and enrichment processes in island arcs. Chemical Geology 165: 67-85.

Bustamante, M.A. 2001. Análisis del contacto MesoCenozoico en el valle del río Volcán, Cordillera de los Andes de la Región Metropolitana. Thesis (Unpublished), Universidad de Chile, Departamento de Geología: 54 p.

Cabanis, B.; Lecolle, M. 1989. Le diagramme La/10-Y/15$\mathrm{Nb} / 8$ : un outil pour la discrimination des séries volcaniques et la mise en evidence des processus de melange et/ou de contamination crustale. Compte Rendus de l'Academie des Sciences 2: 2023-2029.

Charrier, R.; Baeza, O.; Elgueta, S.; Flynn, J.J.; Gans, P.; Kay, S.M.; Muñoz, N.; Wyss, A.R.; Zurita, E. 2002. Evidence for Cenozoic extensional basin development and tectonic inversion south of the flat-slab segment southern Central Andes, Chile ( $33^{\circ}-36^{\circ}$ S.L.). Journal of South American Earth Sciences 15: 117-139.

Drake, R.E.; Vergara, M.; Munizaga, F.; Vicente, J.C. 1982. Geochronology of Mesozoic-Cenozoic Magmatism in Central Chile, Lat. $31^{\circ}-36^{\circ} \mathrm{S}$. Earth-Science Reviews (18): 353-363.
Droop, G.T.R. 1987. A general equation for estimating $\mathrm{Fe}^{3+}$ concentrations in ferromagnesian silicates and oxides from microprobe analyses, using stochiometric criteria. Mineralogical Magazine 55: 431-435.

Dunn, T.; Sen, C. 1994. Mineral/matrix partition coefficients for orthopyroxene, plagioclase, and olivine in basaltic to andesitic systems: a combined analytical and experimental study. Geochimica et Cosmochimica Acta 58, p. 717-733.

Elgueta, S.; Baeza, O.; Aguirre, R.; Charrier, R.; Muñoz, M.; Gans, P. 2000. Mecanismos de la depositación volcanoclástica oligo-miocena en el Cajón del Maipo, Chile central. In Congreso Geológico Chileno, No. 9, Actas: 21-25. Puerto Varas, Chile.

Ewart, A.; Griffin, W.L. 1994. Application of ProtonMicroprobe Data to Trace-Element Partitioning in Volcanic-Rocks. Chemical Geology 117: 251-284.

Féraud, G.; Gastaud, J.; Auzende, J.M.; Olivet, J.L.; Cornen, G. 1982. ${ }^{40} \mathrm{Ar}-{ }^{39} \mathrm{Ar}$ ages for the alkaline volcanism and the basement of Gorringe Bank, North Atlantic Ocean. Earth and Planetary Science Letters 57: 211-226.

Fock, A.; Charrier, R.; Farías, M.; Maksaev, V.; Fanning, M.; Álvarez, P. 2005. Exhumation and uplift of the western Main Cordillera between $33^{\circ}$ and $34^{\circ} \mathrm{S}$. Proceedings of International Symposium on Andean Geodynamics (ISAG), No. 6: 273-276.

Fuentes, F. 2004. Petrología y metamorfismo de muy bajo grado de unidades volcánicas oligoceno-miocenas en la ladera occidental de los Andes de Chile central $\left(33^{\circ} \mathrm{S}\right)$. Ph.D. Thesis (Unpublished), Universidad de Chile, Departamento de Geología: 407 p.

Fujimaki, H.; Tatsumoto, M.; Aoki, K. 1984. Partition coefficients of $\mathrm{Hf}, \mathrm{Zr}$ and REE between phenocryst phases and groundmass. Proceedings 14th Lunar and Planetary Science Conference, Part 2. Journal of Geophysical Research 89: B662-B672.

Godoy, E. 1988. Y Klohn tenía razón: La Formación Colimapu recupera sus miembros basales. In Proceedings of Congreso Geológico Chileno, No. 5, Actas 3: $\mathrm{H} 101-\mathrm{H} 120$.

Godoy, E.; Yañez, G.; Vera, E. 1999. Inversion of an Oligocene volcano-tectonic basin and uplifting of its superimposed Miocene magmatic arc in the Chilean Central Andes: first seismic and gravity evidences. Tectonophysics 306: 217-236.

González, O. 1963. Observaciones geológicas en el valle del río Volcán. Universidad de Chile, Departamento de Geología, Comunicaciones (41): 20-61.

Gorton, M.P.; Schandl, E.S. 2000. From continents to island arcs: a geochemical index of tectonic setting for arc-related and within plate felsic to intermediate volcanic rocks. The Canadian Mineralogist 38: 10651073. 
Gust, D.A.; Perfit, M.R. 1987. Phase relations of a high$\mathrm{Mg}$ basalt from the Aleutian island arc: implications for primary island arc basalts and high-Al basalts. Contributions to Mineralogy and Petrology 97: 7-18.

Hawkesworth, C.J.; Gallagher, K.; Hergt, J.M.; McDermott, F. 1994. Destructive plate margin magmatism: Geochemistry and melt generation. Lithos 33: 169188.

Hickey, R.L.; Frey, F. A.; Gerlach, D.C. 1986. Multiple sources for basaltic arc rocks from the southern volcanic zone of the Andes $\left(34^{\circ}-41^{\circ} \mathrm{S}\right)$ : trace element and isotopic evidence for contributions from subducted oceanic crust, mantle, and continental crust. Journal of Geophysical Research 91: 5963-5983.

Hickey-Vargas, R.; Moreno, H.; López, L.; Frey, F. 1989. Geochemical variations in Andean basaltic and silicic lavas from the Villarrica-Lanín volcanic chain $\left(39.5^{\circ} \mathrm{S}\right)$ : an evaluation of source heterogeneity, fractional crystallization and crustal assimilation. Contributions to Mineralogy and Petrology 103: 361-386.

Hildreth, W.; Moorbath, S. 1988. Crustal contributions to arc magmatism in the Andes of central Chile. Contributions to Mineralogy and Petrology 98: 455489.

Jeffries, T.E.; Perkins, W.T.; Pearce, N.J.G. 1995. Measurements of trace elements in basalts and their phenocrysts by laser probe microanalysis inductively coupled plasma mass spectrometry (LPMA-ICP-MS). Chemical Geology 121: 131-144.

Kay, S. M.; Mpodozis, C. 2002. Magmatism as a probe to the Neogene shallowing of the Nazca plate beneath the modern Chilean flat-slab. Journal of South American Earth Sciences 15: 39-57.

Kay, S.M.; Mpodozis, C.; Coira, B. 1999. Neogene magmatism, tectonism, and mineral deposits of the Central Andes $\left(22^{\circ}-33^{\circ} \mathrm{S}\right.$ latitude). In Geology and Ore Deposits of the Central Andes (Skinner, B.J.; editor). Society of Economic Geologists, Special Publication (7): 27-59.

Kay, S.M.; Godoy, E.; Kurtz, A. 2005. Episodic arc migration, crustal thickening, subduction erosion, and magmatism in the south-central Andes. Geological Society of America, Bulletin 117: 67-88.

Kelley, S. 2002. Excess argon in $\mathrm{K}-\mathrm{Ar}$ and $\mathrm{Ar}-\mathrm{Ar}$ geochronology. Chemical Geology 188: 1-22.

Klohn, C. 1960. Geología de la Cordillera de los Andes de Chile central (provincias de Santiago, O'Higgins, Colchagua y Curicó). Instituto de Investigaciones Geológicas, Boletín (8): 95 p. Santiago.

Kurtz, A.; Kay, S.M.; Charrier, R.; Farrar, E. 1997. Geochronology of Miocene plutons and exhumation history of the El Teniente region, Central Chile ( $34^{\circ}$ $\left.35^{\circ} \mathrm{S}\right)$. Revista Geológica de Chile 24 (1): 75-90.

Larsen, L.M. 1979. Distribution of REE and other traceelements between phenocrysts and peralkaline undersaturated magmas, exemplified by rocks from the Gardar Igneous Province, South Greenland. Lithos 12: $303-315$.
Le Maitre, R.W.; Baterman, P.; Dudek, A.; Séller, J.; Lameyere Le Bas, M.J.; Sabine, P.A.; Schmid, R.; Sorensen, H.; Streckeisen, A.; Woolley, A.R.; Zanettin, B. 1989. A classification of igneous rocks and glossary of terms. Blackwell Scientific Publications: 193 p. Oxford.

Leterrier, J.; Maury, R.C.; Thonon, P.; Girard, D.; Marchal, M. 1982. Clinopyroxene composition as a method of identification of the magmatic affinities of paleovolcanic series. Earth and Planetary Science Letters, 59: 139-154.

Levi, B.; Aguirre, L.; Nyström, J.O.; Padilla, H.; Vergara, M. 1989. Low-grade regional metamorphism in the Mesozoic-Cenozoic volcanic sequences of the Central Andes. Journal of Metamorphic Geology 7: 487495.

McCulloch, M.T.; Gamble, J.A. 1991. Geochemical and geodynamical constraints on subduction zone magmatism. Earth and Planetary Science Letters 102: 258-274.

Medina, C.R. 2001. Condiciones de depositación y deformación de la secuencia miocénica en el sector cordillerano de San Alfonso, Cajón del Maipo, Región Metropolitana, Chile. Thesis (Unpublished), Universidad de Chile, Departamento de Geología: 62 p.

Middlemost, E.A.K. 1975. The basalt clan. Earth Science Reviews 11: 337-364.

Mpodozis, C.; Ramos, V. 1989. The Andes of Chile and Argentina. In Geology of the Andes and its Relation to Hydrocarbon and Mineral Resources (Ericksen, G.E.; Cañas, M.T.; Reinemund, J.A.; editors) . Earth Science Series, Circum-Pacific Council for Energy and Mineral Resources 11: 59-90. Houston, Texas.

Munizaga, F.; Vicente, J.C. 1982. Acerca de la zonación plutónica y del volcanismo miocénico en los Andes de Aconcagua (Lat. $32-33^{\circ} \mathrm{S}$ ): datos radiométricos K-Ar. Revista Geológica de Chile (16): 3-21.

Muñoz, M. 2005. Geoquímica, metamorfismo y petrogénesis de la franja oriental de la Formación Abanico en Chile Central, área de El Volcán, Cajón del Maipo (3350'S, $\left.70^{\circ} 12^{\prime}-70^{\circ} 05^{\prime} \mathrm{W}\right)$. M.Sc. Thesis (Unpublished), Universidad de Chile, Departamento de Geología: 172 p.

Nakamura, N. 1974. Determination of REE, Ba, Mg, Na, and $\mathrm{K}$ in carbonaceous and ordinary chondrites. Geochimica et Cosmochimica Acta 38, p. 757-775.

Nyström, J.O.; Parada, M.A.; Vergara, M. 1993. Sr-Nd isotope compositions of Cretaceous to Miocene volcanic rocks in Central Chile: A trend toward a MORB signature and a reversal with time. Paris ORSTOM Editions. International Symposium on Andean Geodynamics, No. 2, Extended Abstracts: 411-414. Oxford.

Nyström, J.O.; Vergara, M.; Morata, D.; Levi, B. 2003. Tertiary volcanism during extension in the Andean

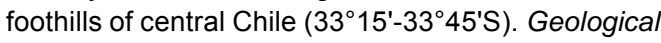
Society of America, Bulletin 115: 1523-1537. 
Pearce, J.A.; Norry, M.J. 1979. Petrogenetic implications of $\mathrm{Ti}, \mathrm{Zr}, \mathrm{Y}$ and $\mathrm{Nb}$ variations in volcanic rocks. Contributions to Mineralogy and Petrology 69: 33-47.

Pearce, J.A. 1982. Trace element characteristics of lavas from destructive plate boundaries. In Andesites: orogenic andesites and related rocks (Thorpe, R.S.; editor). John Wiley: 525-548. Chichester, UK.

Pearce, J.A. 1983. Role of the sub-continental lithosphere in magma genesis at active continental margins. In Continental basalts and mantle xenoliths (Hawkesworth, C.J.; Norry, M.J.; editors). Shiva Publishing Limited: 230-249. Nantwich, UK.

Pearce, J. A.; Parkinson, I.J. 1993. Trace element models for mantle melting: application to volcanic arc petrogenesis. In Magmatic Processes and Plate Tectonics (Prichard, H.M.; Alabaster, T.; Harris, N.B.W.; Neary, C.R.; editors). Geological Society of London, Special Publication (76): 373-403.

Price, R.C.; Stewart, R. B.; Woodhead, J.D.; Smith, I.E.M. 1999. Petrogenesis of High-K Arc Magmas: Evidence from Egmont Volcano, North Island, New Zeland. Journal of Petrology 40: 167-197.

Putirka, K.; Johnson, M.; Kinzler, R.; Longhi, J.; Walker, D. 1996. Thermobarometry of mafic igneous rocks based on clinopyroxene-liquid equilibria, 0-30 kbar. Contributions to Mineralogy and Petrology 123: 92108.

Renne, P.P.; Swisher, C.C.; Deino, A.L.; Karner, D.B.; Owens, T.; de Paolo, D.J. 1998. Intercalibration of standards, absolute ages and uncertainties in ${ }^{40} \mathrm{Ar} /$ ${ }^{39} \mathrm{Ar}$ dating. Chemical Geology, Isotope Geosciences Section 145: 117-152.

Robinson, D.; Bevins, R.E.; Aguirre, L.; Vergara, M. 2004. A reappraisal of episodic burial metamorphism in the Andes of central Chile. Contributions to Mineralogy and Petrology 146: 513-528.

Rollinson, H.R. 1993. Using Geochemical Data: evaluation, presentation, interpretation. Longman Group Limited: 352 p. Essex, England.

Ruffet, G.; Féraud, G.; Ballèvre, M.; Kienast, J.R. 1995. Plateau ages and excess argon in phengites: an ${ }^{39} \mathrm{Ar}$ ${ }^{40} \mathrm{Ar}$ laser probe of Alpine micas (Sesia Zone, Western Alps, northern Italy). Chemical Geology, Isotope Geosciences Section 121: 327-343.

Schock, H.H. 1979. Distribution of rare-earth and other trace elements in magnetites. Chemical Geology 26 119-133.

Shaw, D.M. 1970. Trace element fractionation during anatexis. Geochimica et Cosmochimica Acta 34: 237 243.

Steiger, R.H.; Jäger, E. 1977. Subcommission on geochronology: convention on the use of decay constants in geo-and cosmology. Earth and Planetary Science Letters 36: 359-362.

Stern, C.R. 1991. Role of subduction erosion in the generation of Andean magmas. Geology 19: 78-81.

Stern, C.R. 2004. Active Andean volcanism: its geologic and seismic setting. Revista Geológica de Chile $\mathbf{3 1}$ (2): 161-206

Stewart, R.B.; Price, R.C.; Smith, I.E.M. 1996. Evolution of high-K arc magma, Egmont volcano, Taranaki, New Zealand: evidence from mineral chemistry. Journal of Volcanology and Geothermal Research 74: 275-295.

Tatsumi, Y.; Murasaki, M.; Arsadi, E.; Nohda, S. 1991. Geochemistry of Quaternary lavas from NE Sulawesi: Transfer of subduction components into the mantle wedge. Contributions to Mineralogy and Petrology 107: $137-149$

Tatsumi, Y.; Kogiso, T.; Nohda, S. 1995. Formation of a third volcanic chain in Kamchatka: generation of unusual subduction-related magmas. Contributions to Mineralogy and Petrology 120: 117-128.

Thiele, R. 1980. Hoja Santiago, Región Metropolitana. Instituto de Investigaciones Geológicas, Carta Geológica de Chile (39): 51 p. Santiago.

Vergara, M.; Drake, R. 1978. Edades Potasio-Argón y su implicancia en la geología regional de Chile Central. Universidad de Chile, Departamento de Geología Comunicaciones (23): 1-11.

Vergara, M.; Drake, R. 1979. Edades K/Ar en secuencias volcánicas continentales postneocomianas de Chile Central; su depositación en cuencas intermontanas restringidas. Revista de la Asociación Geológica Argentina 34: 42-52.

Vergara, M.; Charrier, R.; Munizaga, F.; Rivano, S.; Sepúlveda, P.; Thiele, R.; Drake, R. 1988. Miocene volcanism in the central Chilean Andes $\left(31^{\circ} 30^{\prime} \mathrm{S}\right.$ $\left.34^{\circ} 35^{\prime} \mathrm{S}\right)$. Journal of South American Earth Sciences 1: 199-209.

Vergara, M.; Levi, B.; Nyström, J.O.; Cancino, A. 1995. Jurassic and Early Cretaceous island arc volcanism, extension, and subsidence in the Coast Range of central Chile. Geological Society of America ,Bulletin 107: $1427-1440$.

Vergara, M.; Morata, D.; Villarroel, R.; Nyström, J.O.; Aguirre, L. 1999. ${ }^{40} \mathrm{Ar} /{ }^{39} \mathrm{Ar}$ ages, very low grade metamorphism and geochemistry of the volcanic rocks from 'Cerro El Abanico', Santiago Andean Cordillera $\left(33^{\circ} 30^{\prime \prime S}-70^{\circ} 25^{\prime \prime W}\right)$. International Symposium on Andean Geodynamics, No. 4, Extended Abstracts, Georg August Universität: 785-788. Göttingen.

Villemant, B.; Jaffrezic, H.; Joron, J-L.; Treuil, M. 1981. Distribution coefficients of major and trace elements; fractional crystallization in the alkali basalt series of Chaîne des Puys (Massif Central, France). Geochimica et Cosmochimica Acta 45: 1997-2016.

White, W.M.; Patchet, P.J. 1984. Hf-Nd-Sr isotopes and incompatible element abundances in island arcs: implications for magma origins and crust-mantle evolution. Earth and Planetary Science Letters 67: 167-185.

Woodhead, J.D.; Jonson, R.W. 1993. Isotopic and traceelement profiles across the New Britain island arc, 
Papua New Guinea. Contributions to Mineralogy and Petrology 113: 479-491.

Woodhead, J.D.; Eggins, S.; Gamble, J.A. 1993. High field strength and transition element systematics in island arc and back-arc basin basalts: evidence for multi-stage melt extraction and an ultra-depleted mantle wedge. Earth and Planetary Science Letters 114: $491-504$

Manuscrito recibido: Agosto 24, 2005; aceptado: Diciembre 7, 2005. 


\section{APPENDIX 1}

\section{ANALYTICAL METHODS}

Mineral compositions were determined on carbon-coated polished thin sections using a CAMECA SU-30 SEM-Probe at the Departamento de Geología, Universidad de Chile, Chile, and a CAMECA SX100 electron microprobe at the Service Commun Microsonde Sud, Université de Montpellier II, France. The standard operating conditions included an accelerating voltage of $15 \mathrm{kV}$, a beam current of $10 \mathrm{nA}$, a beam diameter of approximately $1-2 \mu \mathrm{m}$, and counting times of 6 to $20 \mathrm{~s}$ depending on the analyzed elements. All analyses were wavelength dispersive. Natural and synthetic standards were used for analyses. Results are considered accurate to within 1-3\% for major and $7-10 \%$ for minor elements.

Altered margins and prominent veins were removed from the samples selected for chemical and isotopic analyses. These samples were then crushed in a reciprocating steel crusher, and subsequently reduced to powder in an agate shatterbox. Whole-rock powders were analyzed for major and trace elements at the: (a) chemical laboratory of the Departamento de Geología, Universidad de Chile (samples MV and RB); major and trace elements, including rare earth elements (REE), were determined by inductively coupled plasma-atomic emission spectrometry (ICP-AES) using a sequential Perkin-Elmer P400, and (2) the Centre de Recherches Pétrographiques et Géochimiques, CNRS, Vandoeuvrelès-Nancy, France (samples VAL); major elements were determined by inductively coupled plasma-atomic emission spectrometry (ICP-AES) using a Jobin-Yvon JY 70 spectrometer, whereas trace elements including rare earth elements (REE) were determined by inductively coupled plasma-mass spectrometry (ICP-MS) using a Perkin-Elmer ELAN 5000 spectrometer. The elements Rb and Ta were analyzed in eleven samples (samples MV and RB) at the chemical laboratory of the Servicio Nacional de Geología y Minería. Rb was determined by atomic emission spectrometry using a Perkin-Elmer 4000 and Ta by plasma-mass spectrometry using a Agilent $7500 \mathrm{~A}$.

Rock powders of samples for $\mathrm{Sr}$ and $\mathrm{Nd}$ isotopic analyses were first dissolved in $\mathrm{HF}, \mathrm{HNO}_{3}$ and $\mathrm{HCl}$ in Teflon beakers, followed by $\mathrm{Sr}$ and $\mathrm{Nd}$ collection by ion exchange and reversed-phase chromatography, respectively. The $\mathrm{Sr}$ and $\mathrm{Nd}$ samples were then loaded onto single Ta and double Re-Ta filaments, respectively. The isotopic compositions were measured using a Finnigan MAT 261 multicollector mass spectrometer at the Swedish Museum of Natural History, Stockholm, Sweden. Chemical and loading blanks for Sr and Nd were negligible. Sr and Nd ratios were corrected for mass fractionation by normalizing to ${ }^{86} \mathrm{Sr} /{ }^{88} \mathrm{Sr}=0.1194$ and ${ }^{146} \mathrm{Nd} /{ }^{144} \mathrm{Nd}=0.7219$, respectively. Eight determinations of the NBS 987 standard gave a mean ${ }^{87} \mathrm{Sr} /{ }^{86} \mathrm{Sr}$ ratio of $0.710244 \pm 0.000042(2 \sigma)$. Nd ratios are reported relative to a value of 0.511854 for the La Jolla standard. Fourteen analyses of the La Jolla standard gave a mean ${ }^{143} \mathrm{Nd} /{ }^{144} \mathrm{Nd}$ ratio of $0.511753 \pm 0.000026$ $(2 \sigma)$. Individual runs of $\mathrm{Sr}$ and $\mathrm{Nd}$ commonly had a precision better than $0.00001(2 \sigma)$. The reported uncertainties on the $\mathrm{Sr}-\mathrm{Nd}$ isotopic compositions are at the $2 \mathrm{~s}$ confidence level.

Four samples of basic lava flows were analyzed by the ${ }^{40} \mathrm{Ar} /{ }^{39} \mathrm{Ar}$ step heating procedure; one on bulk sample of plagioclase and the others on clusters of plagioclase crystals. Grain sizes for the plagioclase bulk sample are 120-180 $\mu \mathrm{m}$ and the analyzed weight for plagioclases was $66 \mathrm{mg}$. Grain sizes for clusters of plagioclase are 100-300 $\mu \mathrm{m}$. Plagioclases were separated using a magnetic separator and then carefully selected under a binocular microscope, in order to avoid altered or inclusion-bearing crystals. The samples were irradiated in the nuclear reactor at the McMaster University in Hamilton, Canada, in position $5 \mathrm{c}$ for 10 and $15 \mathrm{~h}$. The irradiation flux was calculated using the Fish Canyon sanidine (FCs), with an age of $28.02 \mathrm{Ma}$ (Renne et al., 1998), as flux monitor. The maximum flux gradient was estimated at $\pm 0.2 \%$ in the volume where the samples were included. The plagioclase bulk sample were step heated with a high frequency furnace, purified in a pyrex line directly connected to a $120 \% 12 \mathrm{~cm}$ M.A.S.S.E. mass spectrometer working with a Baür-Signer GS 98 source and a Balzers SEV 217 electron multiplier. For clusters of plagioclase, gas extraction was carried out with a $\mathrm{CO}_{2}$ Synrad $48-5$ continuous laser; the mass spectrometer is a VG 3600 working with a Daly detector system. The analytical procedures for clusters of plagioclase and for bulk sample analyses are described in details in Ruffet et al. (1995) and Féraud et al. (1982), respectively. The typical values of Ar isotopic compositions for high frequency furnace analyses were on the order of 20-250, 260-5600, and 4-40 times the blank levels for ${ }^{40} \mathrm{Ar},{ }^{39} \mathrm{Ar}$, and ${ }^{36} \mathrm{Ar}$, respectively. The typical values of $\mathrm{Ar}$ isotopic compositions for the extraction and purification laser system were on the order of 60-200, 140-3200, and 2-8 times the blank levels (measured every third step) for ${ }^{40} \mathrm{Ar},{ }^{39} \mathrm{Ar}$, and ${ }^{36} \mathrm{Ar}$, 
respectively. The criteria for defining plateau ages were the following: (1) it should contain at least $65 \%$ of released ${ }^{39} \mathrm{Ar}$, (2) there should be at least three successive steps in the plateau, and (3) the integrated age of the plateau should agree with each apparent age of the plateau within a $2 \sigma$ error confidence interval. Uncertainties on the apparent ages on each step are quoted at the $1 \sigma$ level and do not include the errors on the age of the monitor. Uncertainties in the plateau, weighted mean and inverse isochron ages are given at the $2 \sigma$ level. The error on the ${ }^{40} \mathrm{Ar}^{*} / 39 \mathrm{ArK}$ ratio $\left({ }^{40} \mathrm{Ar}{ }^{*}\right.$ : radiogenic ${ }^{40} \mathrm{Ar}$ ) of the monitor is included in the plateau age error bar calculation. 